Critical Reviews in Environmental Science and Technology, Vol. 37(3), May 2007 , pp. 199-232

\title{
Weathered hydrocarbon wastes: a risk management primer
}

K.J. Brassington ${ }^{1}$, R.L. Hough ${ }^{1}$, G.I. Paton ${ }^{2}$, K.T. Semple ${ }^{3}$, G.C. Risdon ${ }^{4}$, J. Crossley ${ }^{5}$, I. Hay $^{6}$, K. Askari ${ }^{7}$ and S.J.T. Pollard ${ }^{{ }^{*}}$

${ }^{1}$ Integrated Waste Management Centre, Department of Sustainable Systems, School of Industrial and Manufacturing Science, Cranfield University, Cranfield, Bedfordshire, MK43 OAL, UK.

${ }^{2}$ Department of Plant and Soil Sciences, School of Biological Sciences, Cruickshank Building, University of Aberdeen, Aberdeen, Scotland, AB24 3UU, UK

${ }^{3}$ Department of Environmental Sciences, Institute of Environmental and Natural Sciences, University of Lancaster, Lancaster, LAI 4YQ, UK

${ }^{4}$ TES Bretby, PO Box 100, Bretby Business Park, Burton-on-Trent, DE15 OXD, UK

${ }^{5}$ Dew Remediation Limited, Royds Works, Attercliffe Road, Sheffield, S4 7WZ

${ }^{6}$ Sustainable Manufacturing, PERA, PERA Innovation Park, Melton Mowbray, Leicestershire, LE13 OPB

${ }^{7}$ SLR Consulting Limited, 1 Meadowbank Way, Nottingham, NG16 3TT, UK

*Corresponding author s.pollard@ cranfield.ac.uk; Tel. +44(0)1234 754101; Fax. +44(0)1234 751671

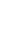


ABSTRACT: We provide a primer and critical review of the characterisation, risk assessment and bioremediation of weathered hydrocarbons. Historically the remediation of soil contaminated with petroleum hydrocarbons has been expressed in terms of reductions in total petroleum hydrocarbon (TPH) load rather than reductions in risk.

There are several techniques by which petroleum hydrocarbons in soils can be characterised. Method development is often driven by the objectives of published risk assessment frameworks. Some frameworks stipulate analysis of a wide range of petroleum hydrocarbons e.g. UK approach suggests compounds from $\mathrm{EC}_{5}$ to $\mathrm{EC}_{70}$ be examined. Methods for the extraction of petroleum hydrocarbons from soil samples have been reviewed extensively in the open literature. Although various extraction and analytical methods are available for petroleum hydrocarbons, their results suffer from inter-method variation with gas chromatography methods being used widely. Currently, the implications for risk assessment are uncertain. Bioremediation works well for remediating soils contaminated with petroleum hydrocarbons. As a result, the optimisation of environmental conditions is imperative. For petroleum hydrocarbons in soil, international regulatory guidance on the management of risks from contaminated sites is now emerging. There is also growing support for the move towards compound-specific risk-based approaches for the assessment of hydrocarbon-contaminated land.

Keywords: weathered, hydrocarbons, environmental, risk, management, remediation. 


\section{INTRODUCTION}

Contamination of land due to anthropogenic activity, both present and historical, is a global problem. It is estimated there may be as many as 100000 contaminated sites in England and Wales alone. Contaminated has become a subject of social, legal, environmental and economic concern within many of the world's industrialised countries ${ }^{107}$. .Land may be contaminated because of past industrial activity, historic disposal practices, or due to an adverse event such as a chemical spill ${ }^{62}$. Although a large proportion of contaminated land may be attributable to historical practices, modern industrial processes also produce potential contaminants and thus, contamination of land is an ongoing problem that requires active management.

Petroleum continues to be a widely utilised resource throughout the world. Its use has resulted in the contamination through accidental spillage and leakage ${ }^{71}$. Certain components of petroleum contamination may pose risks to human health, property, watercourses, ecosystems, and other environmental receptors ${ }^{34,30}$. Petroleum, in its natural state, is a highly complex mixture of hydrocarbons with minor amounts of other heterogenic compounds such as nitrogen, oxygen and sulphur ${ }^{34}$. The composition of petroleum hydrocarbon products can vary substantially depending on the nature, composition, and degree of processing of the source material ${ }^{70}$. Once released to the environment, petroleum products are subject to physical, chemical and biological processes that further change its composition, toxicity, availability and distribution (partitioning) within the environment (Figure 1). Such degradation processes include adsorption, volatilisation, dissolution, biotransformation, photolysis, oxidation, and hydrolysis ${ }^{9,30,50,70,87}$. The extent of weathering experienced is particularly important when characterising petroleum contamination prior to remediation ${ }^{107}$. Whilst there is a large literature describing the composition and properties of petroleum 
products $^{87}$, there is a relative paucity of information on the toxicity, distribution, transport, and availability of weathered hydrocarbons in the environment ${ }^{71,87}$. Here, we provide a primer and critical review of the characterisation, risk assessment and bioremediation of weathered hydrocarbon-fuel products. Current issues are discussed.

As with all contaminants, their chemistry determines which environmental compartment they are found in and thus analysed and is also responsible for their environmental fate and transport characteristics. Analytical methods for determining concentrations of hydrocarbons in the soil need to be technically and economically feasible and capable of analysing the range of compounds key to the risk management protocols applied ${ }^{30}$. Although various extraction and analytical methods are available for petroleum hydrocarbons, their results suffer from inter-method variation as illustrated by Buddhadasa et al. $(2002)^{16}$. Additionally, as discussed by Whittaker et al. (1995) ${ }^{107}$, methods can suffer from both positive and negative analytical bias ${ }^{86}$. Gas chromatography is a widely used technique for the analysis of petroleum hydrocabons ${ }^{47,103,105}$. Biodegradation of more amenable components of the petroleum mixture leads to relative enrichment of the more recalcitrant species. Incomplete resolution of this more recalcitrant mixture leads to a characteristic "humped" appearance of the gas chromatograms output. The "hump" is the resulting signal produced by many hundreds of components such as cyclic and branched hydrocarbons and is widely referred to as the unresolved complex mixture (UCM). The shape and position of the UCM is not constant and depends on the nature of the original petroleum contamination and the extent of degradation that has taken place in the ground. These issues need to be addressed when implementing a national risk-based framework, as differences in analytical approach may inadvertently result in excessive or inadequate remediation being performed.

Risk assessment now is a well-established requirement for the management of contaminated land ${ }^{4}$ and support tool for environmental management decisions. It is widely 
used as a means of assessing and managing potential impacts to human- and ecosystem health $^{4,99}$. Several risk-based frameworks for petroleum hydrocarbons in soil have been published under the auspices of the Total Petroleum Hydrocarbon Criteria Working Group $\left(\mathrm{TPHCWG}^{88}\right)$, the American Society for Testing and Materials $\left(\mathrm{ASTM}^{5}\right)$, the Massachusetts Department of Environmental Protection $\left(\mathrm{MaDEP}^{55}\right)$, the Environment Agency of England and Wales $\left(\mathrm{EA}^{32}\right)$, the American Petroleum Institute $\left(\mathrm{API}^{3}\right)$ and the Canadian Council of Ministers of the Environment $\left(\mathrm{CCME}^{18}\right)$, each reflecting national legislation and socioeconomic issues ${ }^{3,100,101}$. These frameworks, and the exposure assessment methods embedded within them, do not specifically address weathered hydrocarbons, although many acknowledge that petroleum products released to the environment will have undergone some degree of degradation ${ }^{3,6,30,32,55,87}$. Weathering of fresh petroleum product makes it very difficult to accurately predict the composition, toxicity and distribution of petroleum at a given site ${ }^{53}$.

Historically the remediation of soil contaminated with petroleum hydrocarbons has been expressed in terms of reductions in total petroleum hydrocarbon (TPH) load rather than reductions in risk. This still remains as standard practice in a number of countries, examples include Portugal and the $\mathrm{UK}^{30,35}$. Recent stakeholder consultations in the UK, and subsequent publications from the Environment Agency, aim to adopt a risk-based framework where remediation is expressed in terms of risk, consistent with other countries (e.g. America ${ }^{85}$ Canada $^{18}$ and the Netherlands $\left.{ }^{10}\right)^{30-32}$.

There are a plethora of approaches to, and techniques available for, the remediation of contaminated land ${ }^{1,3,20,28,33,48,62,108,109}$. Choice of approach depends on a number of environmental, economic and human health considerations ${ }^{51}$. The UK adopts the 'suitable for use' approach as the most appropriate strategy for the sustainable development of contaminated sites ${ }^{23,43}$. Within the land remediation sector, the EU Landfill Directive ${ }^{80}$ is 
now encouraging the development and implementation of alternative remediation techniques $^{62}$ and is expected to further increase the cost-effectiveness of bioremediation technologies $^{70,77}$. This has resulted in increased interest and use of the technique for the remediation of hydrocarbon-contaminated soils.

A complete understanding of the contaminant in question is a key component when estimating potential risks to human health. To achieve this, adequate information regarding a substance's environmental fate, behaviour and distribution, toxicity, concentration, and potential exposure at a site is essential ${ }^{30}$ (Figure 2). In this review then, we critically review these considerations for the successful implementation of a risk assessment framework for the bioremediation of weathered petroleum hydrocarbons.

\section{CHARACTERISATION OF WEATHERED HYDROCARBONS}

\subsection{Extraction and analysis}

There are several techniques by which petroleum hydrocarbons in soils can be characterised. Method development is often driven by the objectives of published risk assessment frameworks (Table 1) $)^{3,5,6,17,53,88}$. Many frameworks (e.g. TPHCWG, API, CCME, $\mathrm{MaDEP})$ require the quantification of specific indicators and/or fractions; while others consider indicator compounds or chemicals of concern (e.g. ASTM) $)^{3,17,53,87}$ (Section 3 ). It is necessary to use analytical techniques capable of analysing specified aromatic and aliphatic 'fractions' as well as the specific indicator compounds selected by the different protocols (summarised in Table 1 and Section 3 of this review). These compounds are known carcinogens including benzene, toluene, ethylbenzene and xylene (BTEX) and the 16 EPA polynuclear aromatic hydrocarbons $(\mathrm{PAHs})^{1,17,30,53}$. Some frameworks stipulate analysis of a 
wide range of petroleum hydrocarbons e.g. UK approach suggests compounds from an equivalent carbon number (see section 3) of 5 to 70 be examined (Table 1).

\subsubsection{Extraction of petroleum hydrocarbons from soil and class fractionation}

Methods for the extraction of petroleum hydrocarbons from soil samples have been reviewed extensively in the open literature. They include purge and trap (volatiles), headspace (volatiles), manual shaking, Soxhlet, ultrasonic extraction, pressurised fluid extraction, microwave-assisted extraction and super-critical fluid extraction ${ }^{86}$. For heavily weathered fuel oils, extraction of volatile hydrocarbons is rarely considered. Soxhlet extraction is commonly used in research, yet several risk assessment frameworks adopt manual shake methods, e.g. TPHCWG, the Agency for Toxic Substances and Disease Registry (ATSDR) and the Texas Natural Resource Conservation Commission (TNRCC) $)^{1,6,83,86}$. This method involves shaking or vortexing $10 \mathrm{~g}$ (typically) of soil with $10 \mathrm{ml}$ of an appropriate solvent (typically $n$-pentane) for 1 hour, after which an aliquot is drawn for analysis ${ }^{1,59}$. The popularity of manual shake/vortex methods is due to a combination of convenience and cost; being quicker, easier, more accessible and cheaper than Soxhlet extraction, with no concentration step required prior to analysis ${ }^{34,86}$. Additionally legislative analysis requirements within some countries can be met using this method rather than a more exhaustive technique..

Soxhlet extraction ${ }^{34,86}$ is the benchmark method for the $\mathrm{CCME}_{10}-\mathrm{C}_{50}$ hydrocarbon range and a component of the United Sates Environmental Protection Agency (USEPA) methods for semi- and non-volatile organics in soil ${ }^{19,91}$. Soxhlet extraction is a highly exhaustive extraction technique and can handle both air dried and field moist samples, the latter being facilitated through the addition of chemical drying agents, such as anhydrous sodium sulphate, prior to extraction. A wide range of solvent types can be employed making 
this technique versatile for different chromatographic end points. The Soxhlet method generates a relatively large volume of extract requiring concentration prior to chemical analysis. This may be seen as a disadvantage due to potential contamination and losses during concentration steps ${ }^{86}$. However losses can be minimised through the use of methods such as kuderna Danish.

The time taken to extract a sample using Soxhlet extraction and ultimately its cost has initiated investigations into alternative methods. Hawthorne et al. $(2000)^{41}$, for example, reviewed methods available for the extraction of PAHs from historically-contaminated soils. Methods reviewed included Soxhlet extraction, pressurized liquid extraction (PLE), supercritical fluid extraction (SFE) and subcritical water extraction (at 300 and $250^{\circ} \mathrm{C}$ ) (SWE). Comparisons were made between hydrocarbon recovery, the effects on the sample matrix, the presence of co-extracted (non-target) matrix material and the relative selectivity for extracting different classes of target organics.

The authors concluded that extraction methods that are relatively simple to perform yield the 'dirtiest' extracts; while those yielding cleaner more specific extracts required methods that are relatively complex ${ }^{41}$. Soxhlet and PLE yielded much darker and turbid extracts whereas subcritical water extracts were orange to dark orange in colour with moderate turbidity. SFE extracts were light yellow in colour and clear. Soxhlet and PLE yielded more artefact peaks in the gas chromatogram and, due to the extracts from these methods having a high soil matrix content, more frequent cleaning of GC injection ports was required in comparison to SFE extracts ${ }^{41}$. However, the development of GC techniques negates this issue due to enhanced sensitivity allowing the analysis of more dilute samples. Although there were minor differences in extraction efficiencies, the quantitative agreement between the methods was reportedly good ${ }^{41}$. It has also been shown by Hollender et al $(2003)^{45}$ that ultrasonic extraction and accelerated solvent extraction can achieve higher extraction 
efficiencies when extracting PAHs than Soxhlet extraction. Saifuddin and Chua (2003) ${ }^{74}$ compared Soxhlet extraction to microwave-assisted extraction (MAE) ${ }^{74}$. Here, MAE was quicker ( 33mins vs. 24hrs for Soxhlet extraction), used less solvent (4ml of solvent compared to $20 \mathrm{ml}$ for Soxhlet extraction) and capable of slightly higher extraction efficiencies ( $82 \%$ rather than $77 \%$ for Soxhlet extraction). However, samples needed to be free from metallic particles which clearly limits application of this technique to contaminated soils $^{22,34}$. Additionally, although MAE achieved higher extraction efficiencies, there was no significant difference between the data for MAE and Soxhlet extraction $(\alpha=0.05)$, thus the benefit of a slight increase in extraction efficiency is questionable $\mathrm{e}^{74}$.

Soxhlet extraction is considered a harsh method that extracts a fraction closer to the full capacity of the soil for hydrocarbons, rather than a more biologically relevant analogue of extractability ${ }^{73}$. It has been suggested that methods that only extract environmentally relevant pollutant molecules should be used ${ }^{41,73}$. Although any concentration determined by extraction is operationally defined, it may be more appropriate to employ a 'weaker' extraction that may determine a closer analogue of bioavailability and hence potential risk, depending on the use of the data.

Non-petroleum based hydrocarbons may result in spurious or elevated TPH concentrations especially when remediation methods employ the use of bulking materials such as woodchip. In order to limit interference, it is necessary to purify samples prior to analysis $^{107}$. The most commonly used methods of cleanup employ alumina or silica gel (USEPA methods 3611B and 3630C respectively), used by the TPHCWG, ATSDR, TNRCC, CCME and MaDEP risk assessment frameworks ${ }^{1,19,30,53,83}$. This cleanup method also facilitates fractionation into aliphatic and aromatic fractions, which is required by MaDEP, TPHCWG, ATSDR and the EA $\mathrm{EA}^{6,30,32,53,85}$. However it is likely that any moderately polar compounds will be retained in the silica matrix including any which increase in polarity as a 
result of biotransformation. This may be an issue when analysing weathered hydrocarbon wastes and those undergoing remediation. Attempts to automate the fractionation procedure have resulted in incomplete resolution of the aliphatic and aromatic fractions. Whilst come well resolved components could be eliminated by subtraction, incomplete separation does not address any UCM present. The key fractions affected involve the mono- and di-aromatics.

Extracted samples often need to be concentrated prior to analysis, and before and/or after cleanup steps where an unacceptable level of dilution may be introduced e.g. Soxhlet extraction $^{34,86,93}$ and class fractionation ${ }^{34,86,98}$. There are several concentration methods that can be used: Kuderna Danish concentration, nitrogen evaporation, and rotary evaporation. A concentration step is further source of error. For example, identification errors may occur if samples are evaporated too exhaustively during sample preparation using methods such as rapid nitrogen evaporation, where volatile components are most likely to be $\operatorname{lost}^{50}$. The use of a keeper solvent such as acetonitrile and methods such as Kurderna Danish, as specified by the USEPA Soxhlet extraction protocol, are considered to minimise such losses ${ }^{86}$.

Due to the wide carbon range covered by hydrocarbon products and the tiered nature of some risk assessment frameworks, it is clear that no single analysis technique is likely to be sufficient for analysing soil samples. It would seem sensible that if a tiered risk assessment is used then a systematic tiered analysis strategy be matched to it, as progression to higher tiers and thus higher levels of analytical complexity may not in all situations be necessary. The use of tiered analytical approaches are increasingly being applied in oil spill identification ${ }^{102,103}$. For example, Wang et al. (1997) ${ }^{102}$ used a 5 tiered analytical approach that enabled the identification of oil type, degree of weathering and biodegradation.

Many of the risk assessment frameworks for petroleum hydrocarbons specify preferred extraction and analytical techniques; some having published their own recommended methods (CCME, TNRCC, TPHCWG and MaDEP ${ }^{19}$; Table $1^{1,56,57,83}$ ). The majority specify 
manual shake or vortexing methods with an appropriate solvent to extract the sample, followed by alumina or silica gel clean up and fractionation into aliphatic and aromatic compounds ${ }^{1,30,53,83}$. The MaDEP approach specifies volatile petroleum hydrocarbon (VPH) and extractable petroleum hydrocarbon (EPH) determinations. The VPH method uses a purge and trap approach, whereas the EPH method specifies extraction using dichloromethane (DCM), cross-referring to the USEPA extraction method followed by silica cleanup and fractionation prior to analysis ${ }^{56,57}$. The CCME method specifies purge and trap for the fraction range $\mathrm{C}_{6}-\mathrm{C}_{10}$, or Soxhlet extraction followed by silica gel clean up and fractionation for the $\mathrm{C}_{10}-\mathrm{C}_{50}$ range ${ }^{19}$. However, it is stated that suitable alternative techniques can be used on the condition that validation data can demonstrate that the alternative method provides data comparable to the benchmark protocol ${ }^{19}$. The CCME method allows for use of USEPA methods, adding further quality control measures ${ }^{19}$. Although in prescribing methods the CCME is also allowing laboratories to use in-house methods, the validation requirement of these methods should ensure the production of comparable data across laboratories with the presumption of comparable risk assessment and remediation outcomes. Neither the EA nor ASTM specify methods for the extraction of petroleum hydrocarbons in risk assessment, however the EA is to adopt performance criteria rather than prescribing specific approaches ${ }^{5,32}$. Here, as with the CCME, the emphasis is on quality and reliability of data rather than the use of specific 'gold standard' techniques.

\subsubsection{Methods for analysis of petroleum hydrocarbons}

The techniques used for the analysis of petroleum hydrocarbons can be grouped by their measurement outcome: quantitation of the petroleum hydrocarbon load; of the concentration of different groups of hydrocarbons; or the concentration of specific target compounds ${ }^{86}$. There are also methods for the rapid on-site screening of contaminated soils. However, the 
majority of these are based on the measurement of vapours derived from the vadose zone by either in situ soil gas measurements or headspace analysis. In the case of weathered petroleum hydrocarbons, the relevance of such methods will depend upon time and alteration mechanisms. Further analysis would also be required to enable the analysis of components with low volatility present within weathered hydrocarbons ${ }^{107}$.

Methods that generate total petroleum hydrocarbon concentrations and group (fraction) concentrations are considered to be non-specific techniques ${ }^{103}$. These generate basic information that is a surrogate for contamination, e.g. a single TPH concentration. Such data are not suitable for risk assessment in isolation ${ }^{34,86}$. However, they are inexpensive, quick and easy and, as such, can offer a useful screening tool ${ }^{34,86}$. The most commonly used specific methods include gas chromatography (GC), gas chromatography mass spectrometry (GC-MS), gas chromatography with flame ionization detection (GC-FID), infrared spectrometry (IR), thin layer chromatography (TLC) and gravimetric analysis ${ }^{86}$. Gas chromatographic methods are the most preferred TPH measurement techniques as they offer relative sensitivity, selectivity, and can be used to identify risk critical compounds. As the compositions of crude oil and petroleum products are highly complex and display a high degree of between-oil variation, unique chemical 'fingerprints' for each oil can be isolated. These can be used to aid identification of the source of weathered oil contamination ${ }^{103}$. Techniques such as GC require additional skills/experience compared to other methods and require that samples are volatile at the operating temperature of the column ${ }^{22}$. Issues also arise with co-elution of compounds as petroleum hydrocarbons comprise many isomers with similar boiling points and thus retention times. Weathered hydrocarbons typically exhibit low volatility, high boiling temperatures and require high column operating temperatures. This can vary depending upon the starting product and whether sorbed or mobile fractions are under analysis. GC techniques can be adapted to enable the analysis of specific hydrocarbon 
ranges, such as gasoline range organics (GRO) and diesel range organics (DRO) ${ }^{34}$ but are often unable to resolve a large proportion of UCMs, characteristic of weathered petroleum hydrocarbons ${ }^{107}$. This may become an issue as more toxicological data becomes available in the future.

Gas chromatography coupled with mass spectrometry detection (GC-MS) is routinely applied for the identification and measurement of individual petroleum hydrocarbons. These methods have a high level of selectivity, with the ability to confirm compound identity though the use of retention time and unique spectral patterns. GC-MS requires specialist operation and interpretation of the data and, as such, it can be more expensive that other GC methods depending on the market forces. GC-MS offers target analyte confirmation, nontarget analyte identification and can be used to separate hydrocarbon classes ${ }^{47}$. Even with ready benchtop availability, some jurisdictions have felt unable to recommend GC-MS analysis of petroleum hydrocarbons to inform risk assessments ${ }^{47}$. The analysis requirements of current frameworks can be easily met, relatively cheaply by GC-FID. The MaDEP method adopts GC-FID methods along with the majority of risk assessment frameworks.

In response to the difficulties with traditional methods for the analysis of weathered petroleum hydrocarbons, alternative and specialised methods have been developed ${ }^{107}$. Whittaker et al., in reviewing both conventional and novel analytical techniques for the characterisation of refractory wastes, highlighted several of these including simulated distillation gas chromatography (GC-SIMDIS), thin-layer chromatography with flame ionisation detection (TLC-FID), high-performance liquid chromatography (HPLC) and laser desorption laser photoionisation time-of-flight mass spectrometry $\left(\mathrm{L}^{2} \mathrm{TOFMS}\right)^{107}$.

The coupling of curie point pyrolysis to GC-MS (Py-GC-MS) is an alternative method to conventional techniques for the analysis of non-volatile compounds such as rubbers, paints and synthetic plastics and has been applied to several sample matrices including soil ${ }^{15}$. 
Recently, Buco et al. evaluated this technique for the analysis of the 16 PAHs included in the USEPA priority pollutant list, and demonstrated repeatability within the range of classic techniques (RSD $=3.4 \%)$ with good accuracy for the measured PAHs ${ }^{15}$. This technique is quick, involves no cleanup and does not require an extracting solvent. Particularly effective for low-molecular-mass PAHs, high molecular mass PAH quantification was complicated by reduced sensitivity. This may limit Py-GC-MS use for analysis of weathered petroleum hydrocarbons ${ }^{15}$. Additionally the small sample volume used makes the homogenization of samples critical for accurate analysis ${ }^{15}$. These authors concluded that Py-GC-MS is suited to use as an alternative screening method for contaminated soil or sediment ${ }^{15}$.

\section{RISK MANAGEMENT FRAMEWORKS FOR HYDROCARBONS}

Risk assessments should provide an "objective, scientific evaluation of the likelihood of unacceptable impacts to human health and the environment" ${ }^{\prime 65}$. Where a 'pollutant linkage' between the source of a hazard and a receptor is present ${ }^{3,70,103,105}$, estimates of exposure are often used to characterise risks to human health, comparing the potential intake of contaminants with acceptable or tolerable intakes inferred from toxicological or epidemiological studies. Many risk assessment frameworks adopt a three tiered approach with increasingly sophisticated levels of data collection and analysis ${ }^{5}$. As assessors move through the tiers, the generic and conservative approach of the earlier tiers is replaced with more detailed and site-specific assumptions ${ }^{3,5,30}$, although each tier aims to be protective of human health ${ }^{3-5,30,32,55}$. The progression to higher tiers involves additional cost due to increased analytical and site investigation requirements. This expenditure enables a more complete characterisation of contaminants resulting in a more comprehensive risk assessment 
and more cost-effective corrective action (risk management) plans ${ }^{5}$. Site-specific assumptions resulting from use of the higher tiers may increase the cost-effectiveness of the remediation, and so assessors need to balance the increased cost and time against potential benefits before proceeding to the next level ${ }^{5}$. Cost-benefit analysis techniques are built into some risk assessment frameworks to facilitate decision making for tier transission ${ }^{3}$.

Different countries and organisations consider aspects of risk assessment frameworks differently. For example, residential exposure scenarios have not been considered as relevant in the API framework ${ }^{3}$. This is because the most realistic future use for exploration and production $(\mathrm{E} \& \mathrm{P})$ sites are for ranch, agricultural or parkland land uses.

Hydrocarbon-contaminated soils contain many hundreds of different compounds. Although it may be feasible to identify each of the compounds present, this would be unnecessarily time consuming. Further, data describing the toxicity, partitioning, fate and transport characteristics of the different compounds are not currently available ${ }^{3,55}$. Identification and assessment of all compounds would be burdensome which would not be practicable for stakeholders ${ }^{30,32}$. Therefore, surrogate measures for carbon fractions of toxicological significance, such as boiling point and carbon number ranges, have been used to simplify the assessment process ${ }^{5}$. Furthermore, risk management frameworks have focused on a limited subset of key components, using broad observations regarding the characteristics of known petroleum hydrocarbons to group compounds into fractions and identify key toxic compounds for use as indicators ${ }^{3,5}$. Typically, petroleum fractions are used to consider threshold health effects while indicator compounds are used to evaluate non-threshold health effects $^{32}$.

Approaches such as the $\mathrm{ASTM}^{5}$ risk-based corrective action (RBCA) framework use indicator compounds as a surrogate for risk. This approach was deemed by $\mathrm{MaDEP}^{53}$ as insufficient for characterising risks posed at a petroleum hydrocarbon release site and 
fractions were introduced. The definitions of specific fractions are derived from either the carbon number $\left(\mathrm{C}_{\mathrm{n}}\right)$ or equivalent carbon $(\mathrm{EC} n)$ number. For example, MaDEP uses fractions to evaluate the threshold contaminants and indicator compounds (or 'target analytes') to evaluate non-threshold toxicity ${ }^{5,30,53}$. The MaDEP approach is one of the few approaches that use carbon numbers. Here TPH fractions are based upon "chemical structure, carbon number, and structure activity relationships" ${ }^{\prime 54}$. The majority of frameworks use equivalent carbon numbers $\left(\mathrm{EC}_{n}\right)$, e.g. $\mathrm{TPHCWG}{ }^{30}$ because these are considered more closely related to the mobility of a compound in environmental media ${ }^{30}$. As such, ECn are based on "a range of physical-chemical properties and simple partitioning models» ${ }^{\sharp 4}$. In practice, the boiling point of the compound of interest on a non-polar GC column is used to derive $\mathrm{EC}_{n}$, assuming the relationship between boiling point and $\mathrm{EC}$ is the same for both aromatics and aliphatics. In characterising the toxicity of a fraction, surrogate compounds or mixtures that are well characterised and characteristic of a particular fraction are often used ${ }^{30,87}$.

The validity of the equivalent carbon number may be challenged. For example, the TPHCWG derive $\mathrm{EC}_{n}$ using a simple empirical binomial model parameterised using data describing the boiling point $\left(\mathrm{T}_{\mathrm{B}},{ }^{\circ} \mathrm{C}\right)$ and carbon number of 75 key hydrocarbons; where $\mathrm{K}_{1}$ and $\mathrm{K}_{2}$ are empirical constants, and $\mathrm{C}$ is the intercept (Equation 1).

$$
E C_{n}=K_{1}\left[T_{B}\right]^{2}+K_{2}\left[T_{B}\right]+C
$$

At best, this provides only a rough estimate of $\mathrm{EC}_{n}$ (e.g. a measured $\mathrm{EC}$ value of 31.3 for benzo[a]pyrene compared to the calculated value of 30.0 using Equation 1). Also, a $\mathrm{T}_{\mathrm{B}}$ of 548 should relate to $\mathrm{EC}_{44}$, however calculating this from Equation 1 provides a value of $\mathrm{EC}_{34.6}$. Clearly there is a disparity between the TPHCWG model and the empirical data. Different parameterisations will have an effect on calculated $\mathrm{EC}_{n}$. Figure 3 shows a series of fitted binomial models based on four different parameterisation data sets. As the boiling point 
increases, a clear disparity emerges between the $n$-alkanes and the PAHs. This can be seen most clearly in the "empirical" plot (Figure 3), between boiling point 450 and $550{ }^{\circ} \mathrm{C}$, where PAHs have markedly lower EC numbers than the $n$-alkanes. Figure 3 suggests that the $\mathrm{EC}_{n}$ approach is unsuitable, particularly for substances EC $>20$. Simple empirical models, such as Equation 1, do not hold true; and the theory that $\mathrm{T}_{\mathrm{B}}$ can be used to calculate $\mathrm{EC}_{n}$ representative of normalisation to the $n$-alkanes appears to be incorrect. However, the implications for risk assessment are likely to be minimal, considering the heterogeneity of soils.

Aromatic and aliphatic compounds differ in their toxicity, solubility and fate and transport characteristics ${ }^{55}$. Because of this, and the evidence shown in Figure 3, some frameworks employ fractions where aliphatic compounds are considered separately to aromatic, which are further fractionated by (equivalent) carbon number (Table 2). Each fraction may then be treated as if it were a separate compound in the environment ${ }^{3,53,87}$ However, the 'New Zealand Approach' ${ }^{60}$ only considers aliphatic fractions while the aromatic faction is addressed separately by direct measurement of BTEX and PAH concentrations $^{30}$.

Toxicity values are assigned to the fractions and indicators used. This is achieved through the process of review and/or extrapolation of available toxicological data on hydrocarbon mixtures and specific hydrocarbon compounds ${ }^{54}$. The number of fractions and their ranges vary between frameworks (Table 2), and in general build upon or adapt the fractions defined by TPHCWG and MaDEP. Various bodies have adapted these ranges. For example, The New Zealand approach uses three aliphatic fractions, while the TPHCWG approach employs 13 analytical fractions (6 aliphatic, 7 aromatic) covering the range from $\mathrm{EC}_{5}-\mathrm{EC}_{35}{ }^{30,55,84,85}$.

The API extended the fractions used by the TPHCWG so that there is a $>\mathrm{EC}_{21}-\mathrm{EC}_{44}$ aromatic fraction and $\mathrm{a}>\mathrm{EC}_{16}-\mathrm{EC}_{44}$ fraction along with an additional $\mathrm{EC}_{44+}$ combined 
aliphatic and aromatic fraction (as it is not physically possible to separate hydrocarbons of this size into fractions) $)^{3}$ (Table 2). This step was taken due to the TPHCWG fractions not encompassing hydrocarbons with carbon numbers greater 35 which can make up to $60 \% \mathrm{w} / \mathrm{w}$ of some crude oils ${ }^{3}$ and is characteristic of weathered hydrocarbons. It was also considered that the TPHCWG fractions were appropriate for most refined products but not the crude oils present at the majority of E\&P sites ${ }^{3}$. Toxicological and fate and transport data for these heavier hydrocarbons $\left(>\mathrm{EC}_{35}\right.$ ) are sparse ${ }^{55}$. As such, the API assigned the characteristics of the next closest aliphatic or aromatic carbon number fractions to the $\mathrm{EC}_{35}-\mathrm{EC}_{44}$ aliphatic and aromatic ranges $3,6,30,54,87$ deriving oral and dermal reference doses of $0.03 \mathrm{mg} / \mathrm{kg} / \mathrm{day}$ and $0.8 \mathrm{mg} / \mathrm{kg} /$ day respectively (as $\mathrm{EC}_{44}$ has extremely low volatility no inhalation reference dose was set by $\mathrm{API}^{3}$ ). The EA approach extends these carbon ranges further (Table 2), resulting in 16 fractions, giving an overall range from $\mathrm{EC}_{5}-\mathrm{EC}_{70}$. Further to the TPHCWG fractions, the $\mathrm{EA}$ added an aromatic $\mathrm{EC}_{35}-\mathrm{EC}_{44}$ range, an aliphatic $\mathrm{EC}_{35}-\mathrm{EC}_{44}$ range and a combined aromatic and aliphatic $\mathrm{EC}_{44}-\mathrm{EC}_{70}$ range $\mathrm{e}^{30,32}$. Research is currently underway to examine the implications of this extended set of hydrocarbon ranges ${ }^{68}$. The use of surrogate data from the next closest hydrocarbon fraction may be overly conservative and thus not cost-effective. In the case of the API approach, the next closest fraction usually encompasses petroleum hydrocarbons with lower molecular weights, and as such would be characterised with a greater degree of mobility within the environment ${ }^{3}$. Further research into the characteristics of heavier compounds may provide a more complete understanding of their behaviour within the environment and potential risks to human health. It could also potentially result in a reduction in the analysis and remediation requirements enabling the risk assessment to become more streamlined.

\section{BIOREMEDIATION}


The bioremediation of contaminated soils has been extensively reviewed. Bioremediation methods utilise naturally occurring biological processes to transform, decrease or eliminate polluting substances ${ }^{13,28,33,40,62}$. Theoretically, optimal conditions are provided for bacteria or fungi to degrade or transform more complex compounds (e.g. contaminants) into relatively simple constituents that may pose a lesser potential risk to humans or ecosystems. An idealised bioremediation method would use harmless reagents, enable the process to be carried out quickly and efficiently (on-site), and result in an acceptable soil product that can be re-used with little/no further modification ${ }^{15}$. Compared to other remediation approaches, bioremediation often has greater analytical and process control requirements. From an engineering perspective, the processes and logistics of bioremediation are relatively simple ${ }^{33}$. Any increased expense due to greater analytical and process requirements is usually offset by lower capital costs ${ }^{20,33}$. In 2000, an EA survey indicated that organic pollutants accounted for $83 \%$ of contaminants remediated at contaminated sites in England and Wales ${ }^{30}$, demonstrating the applicability of bioremediation within the UK land remediation sector.

The disadvantages of bioremediation include the potential unpredictability of performance, difficulties in scaling up from laboratory to field and relatively long (weeks/months) remediation times. Bioremediation is not universally suitable for all contaminants $^{48}$. High concentrations of heavy metals and other highly toxic compounds can be prohibitive of microbial growth ${ }^{48}$, or still leave the remediated soil unfit for purpose and classed as contaminated due to the residual presence of inorganic contaminants. Although bioremediation can breakdown potentially toxic contaminants, this process may result in the formation of metabolites that are toxic in their own right ${ }^{33}$. Contaminants need to provide an energy and carbon source to enable microbial growth, and so need to be biologically 
degradable or transformable $\mathrm{e}^{27,48}$. Hence, biological remediation systems are more suited to organic contaminants, including weathered petroleum hydrocarbons ${ }^{48}$.

\subsection{Bioremediation techniques}

The choice of bioremediation technique can depend on a number of site specific factors, including the type, mobility, concentration and volume of a contaminant, the soil structure, surrounding geology, the proximity to structures and potential receptors, and intended end use $^{13,20,28,33,62}$. There is no single method for every situation and often combinations of techniques are implemented at sites with multiple contamination sources. Bioremediation processes can be divided into in-situ and ex-situ. In-situ methods include monitored natural attenuation $^{12,13,28,43,48,58,62}$, biosparging ${ }^{13,25,62}$ and bioventing ${ }^{13,33,36,48,62}$. They have the advantage of not requiring the excavation or removal of soil ${ }^{13,20,33,62}$. They are able to deal with deep contamination and enable remediation both under and around buildings ${ }^{20}$. These techniques minimise problems with dust, and hence worker exposure may be reduced ${ }^{20,33,62}$. In-situ techniques can adapt, enhance and control bioremediation conditions. However, they are limited by the degree of process control that can be used. In comparison, ex-situ methods are contained and offer a higher degree of process control with greater control over time ${ }^{27}$. Techniques can be performed on or off site depending on the restrictions present at a particular site ${ }^{20}$. Overall, ex-situ methods are considered to be more efficient than in-situ techniques ${ }^{13}$ and can deal with higher concentrations of contaminants ${ }^{27} . E x$-situ techniques include landfarming, composting, biopiling and bioreactor treatments ${ }^{33}$.

'Landfarming' (also known as 'land treatment') is a simple technique used to treat large areas of land. Land farming has been used for the remediation of many waste types, but mainly for the remediation of hydrocarbon contaminated soils ${ }^{13,20,46}$. Landfarming involves the excavation and spreading (to $0.3-0.5 \mathrm{~m}$ thickness $^{28}$ ) of contaminated soil over a bunded 
area (incorporating a leachate collection system and impermeable liner material ${ }^{13,28,62}$ ) which is tilled to aerate the soil at regular intervals ${ }^{20,28,33}$. Composting is an aerobic process using systems that involve the construction of piles, often using bulking agents to increase porosity and facilitate airflow ${ }^{13,33}$. Anaerobic conditions can also be used to compost wastes; however, this can result in the synthesis of unpleasant odorous compounds such hydrogen sulphide $^{20}$ and the generation of methane. Purpose built closed reactor composting systems can be used to compost wastes, and have been used as the basis of soil treatment centres in mainland Europe ${ }^{13,20,62}$. Here, the soil is combined with water to form a slurry which is continuously mixed using mechanical agitators, giving rise to improved contact between the pollutants and the microorganisms ${ }^{33,62}$. Closed systems provide a high degree of process control over environmental conditions and allow for the control and treatment of volatile compounds. However they are more expensive than open systems such as windrows ${ }^{33}$.

Engineered biopiles are an intensive static pile version of composting that enable greater control over important environmental factors that effect biotransformation rates (i.e. oxygen, water and nutrient levels ${ }^{13}$ ) compared to other methods. This intensive method is especially useful when space is limited ${ }^{13}$. Details regarding biopile design and operation can be found elsewhere $\mathrm{e}^{11,13,20,28,40}$.

As highlighted by some of the responses to the EAs survey ${ }^{27}$, the timescale in which pollutants can be remediated is an important consideration when selecting the most appropriate remedial treatment to use at a given site. Cost, guaranteed insurance, and risk reduction were also cited as reasons for not using bioremediation methods. Engineered biopiles offer a high degree of control, have a smaller footprint and are comparatively quick, yet they are not as expensive as closed bioreactor systems ( $£ 10-40$ per $\mathrm{m}^{3}$ vs. $\sim £ 30-150$ per $\left.\mathrm{m}^{3}\right)^{13}$. This makes biopiling attractive to contaminated land remediation specialists, 
especially as the high degree of control allows the processes to be optimised for biotransformation of specific pollutants of interest.

Bioremediation works well for remediating soils contaminated with petroleum hydrocarbons ${ }^{36,49}$. Most studies have reported biotransformation to be rapid in the initial stages of bioremediation, with rates seen to asymptote as the weathered proportion is biotransformed ${ }^{26,37,111}$. Weathered petroleum hydrocarbons have typically been present in the soil for a long period of time, they display relatively low bioavailability, and thus are more recalcitrant in the environment ${ }^{40}$. As a result, the optimisation of environmental conditions is imperative for the remediation of land contaminated with weathered petroleum hydrocarbons ${ }^{40}$. Giles et al. (2001) studied the bioremediation of weathered oil sludge $\left(\mathrm{C}_{20^{-}}\right.$ $\mathrm{C}_{38}$ ) in composting piles. A biotransformation of $97 \% \% \mathrm{w} / \mathrm{w}$ TPH was achieved after 10 weeks. This study showed that indigenous bacterial populations were more suited to biotransforming the sludge ${ }^{28}$. Unexpectedly, the bulking agent used had a greater effect on biodegradation than augmentation with a consortia of oil-degrading bacteria. The authors suggested that the bulking agent achieved higher degradation rates (complete compost) due to the presence of indigenous hydrocarbon-degrading microorganisms. However, this may have been due in part to the increased adsorption capacity of the amended soil matrix. It was suggested that this material was effective at modulating the temperature thus maintaining the bacteria within their optimal range ${ }^{38}$.

\subsection{Optimising bioremediation}

Contaminated soils usually contains a number of microbial species capable of degrading the contaminants present ${ }^{28}$. The degradation process can be enhanced through biostimulation and bioaugmentation. The former refers to the enhancement of the bioremediation process by optimising specific environmental parameters such as temperature, $\mathrm{pH}$, oxygen partial 
pressure, moisture and nutrient levels ${ }^{33,62}$. The latter describes the augmentation of bioremediation systems with commercially available microbial cultures which, in some cases, perform specific functions ${ }^{13,28,40,62}$. Bioaugmentation may be required where native microbial populations are insufficient to achieve effective biotransformation. For example

Phanerochaete chrysosporium (white rot fungus) can aid in the degradation of problematic recalcitrant compounds ${ }^{28}$. However, it should be noted that resulting increased costs are rarely justified by the benefits ${ }^{28}$. Additionally, it was shown by Trindade et al. $(2005)^{89}$ and Giles et al. $(2001)^{38}$ that indigenous micororganisms can be better adapted and more resistant to the contaminants present, with greater remediation potential than foreign organisms ${ }^{28,38,89}$. Typically, the addition of foreign organisms are not required when degrading hydrocarbons ${ }^{11}$. To grow, microorganisms require an electron donor (source of energy) and an electron acceptor as a means of extracting energy from the electron donor. Thus, electron acceptors play a key role in the biotransformation of a contaminant (the energy source - electron donor). Potential electron acceptors for microbial activity are (in order of energy yield, highest first): oxygen, nitrate, iron, manganease, sulphate, carbon dioxide and organic carbon $^{49}$. Clearly as oxygen yields the highest amount of energy it is the preferred electron acceptor and is important to optimise its diffusion into- and concentration within the soil matrix (typically need to keep oxygen in the soil gas $>2 \%$ ).

Different bacterial classes require different temperature ranges to achieve optimum growth. For example, mesophiles grow from about $15^{\circ}$ to $45^{\circ} \mathrm{C}^{49}$ whereas thermophiles grow best between $45^{\circ}$ and $65^{\circ} \mathrm{C}^{33,49}$. Typically during bioremediation mesophilic temperatures are common, with Giles et al. $(2001)^{38}$ having found optimum growth for the bacteria present during the bioremediation of a weathered oil sludge to be less than $45^{\circ} \mathrm{C}^{38}$.

The $\mathrm{pH}$ of the soil can inhibit microbial activity and also affect the solubility of important nutrients such as phosphorus ${ }^{33,49}$. The typical optimum $\mathrm{pH}$ range for 
bioremediation is from $\mathrm{pH} 5.0-9.0$, with a $\mathrm{pH}$ of 7.0 being preferable. Giles et al. $(2001)^{38}$ reported a soil $\mathrm{pH}$ of 6.1 during the bioremediation of a weathered oil sludge, suggesting that the 'typical' bioremediation $\mathrm{pH}$ range is likely to be suitable for weathered petroleum hydrocarbons.

Water is essential for microbial growth and maintenance and also serves as a transport medium though which organic compounds, contaminants and nutrients are transported into the cells and waste products from the cells ${ }^{33,49}$. Achieving a suitable water balance within the biopile can be critical as dry zones may result in decreased microbial activity ${ }^{33}$. Conversely, saturation inhibits gas exchange resulting in anaerobic conditions ${ }^{33}$. The typical optimum water content range is within $55-80 \%$ by weight of the water-holding capacity ${ }^{13,49}$. Bacteria also require nutrients (carbon, nitrogen, phosphorous, and in lesser quantities potassium, sodium, magnesium, calcium, iron, chloride and sulphur ${ }^{13}$ ) for the assimilation and synthesis of new cell materials ${ }^{13,33,49}$. The depletion of nutrients can effect the biotransformation of contaminants, in response biroemediation systems can be amended with fertilisers containing appropriate quantities of the rate-limiting nutrients ${ }^{11,40}$.

It is clear that successful bioremediation relies on the optimisation of several parameters. Thus, prior to the remediation of contaminated land it can be useful to assess the treatability of the soil and identify requirements for bioremediation.

\section{DISCUSSION}

The preceding sections of this review have provided an overview of the issues for the management of risks from weathered hydrocarbons. Summarising this material is insightful in that it illustrates trends and approaches from a variety of perspectives. The view expressed 
is that thirty years of research into petroleum microbiology and bioremediation have bypassed an important observation - that many hydrocarbon-contaminated sites posing potential risks to human health harbour weathered, 'mid-distillate' or heavy oils. These sites present considerable challenges to remediation over and above those posed by fresh or more refined petroleum distillates. Critically, there are important scientific components that drive risk management for these wastes and specifically the partitioning of risk-critical compounds within the oil/soil matrix.

Whilst early work suggested the recalcitrance of these wastes to microbial breakdown, we now know that the risks from these wastes can be actively managed through optimising treatment process parameters during bioremediation. This said, the 'in-field' verification of ex-situ technologies such as biopiling, continues to be expressed in many countries in terms of reductions in total petroleum hydrocarbon (TPH) load, or 'losses' from the soil being treated, rather than by reference to reductions in risk. An observation from the UK is that the absence of risk from the vocabulary of many remediation operators and remediation projects reduces stakeholder (regulatory, investor, landowner and public) confidence in technology performance, and in doing so, limits the market potential of these technologies.

For weathered hydrocarbon wastes, risk management decisions are complicated by the gross complexity of the source term, the effects of weathering on the bioavailability of risk critical contaminants and the variable performance of remedial technologies under authentic site conditions. For heavy oils (the viscous (50-360 mPa s), high-boiling (ca. $300->600{ }^{\circ} \mathrm{C}$ ) products such as No. 6. fuel oil with carbon ranges in excess of $\mathrm{C}_{20}$ ), their inherent complexity is further compounded as they weather in the environment on account of biotic and abiotic losses that shift their chemical composition towards recalcitrant, asphaltenic products of increased hydrophobicity. 
These changes raise an important feature of hydrocarbon contaminated land that is often overlooked - that the source term, the oil matrix, is itself a strong partition medium for risk critical compounds and weathering imparts further hydrophobicity to the oil matrix. Compositional changes dramatically affect the partitioning behaviour of these source terms prior to, during and following biological treatment. Risk critical components (e.g. the higher ring polynuclear aromatic hydrocarbons $(\mathrm{PAH})$ ) in weathered oils are less bioavailable because they are effectively partitioned within the source term in accordance with Raoult's Law. Sun and Boyd $(1991)^{78}$ first suggested the concentration of residual oil within a oil-soil matrix required for it to act as a discrete partition medium $(c a .1000 \mathrm{mg} / \mathrm{kg})$ and suggested that this residual oil, as the original source of priority contaminants, could typically be ten times more an effective partition medium than soil organic matter for hydrophobic organics. This is rarely represented within the fate and transport models that support the environmental exposure assessment of hydrocarbons with the possibility that regulatory exposure assessment models may dramatically over estimate the availability of risk-critical compounds through exposure routes. There is prior art here. Zemanek et al. (1997) ${ }^{113}$ showed that between $71-96 \%$ w $/ \mathrm{w}$ of PAH in weathered diesel-contaminated loam soils were partitioned to residual oil (at 2-6\%w/w of the total soil composition) in petroleum and weathered creosotecontaminated soils, with $84 \% \mathrm{w} / \mathrm{w}$ of benzo[ $[a]$ pyrene partitioned to the residual oil phase. Woolgar and Jones (1999) ${ }^{110}$ estimated oil - water partition coefficients (termed $\log \mathrm{K}_{\mathrm{mw}}$ ) for a series of PAH to be between $4.5-6.5$, dependent on the source term. Under these conditions, highly partitioned constituents in weathered hydrocarbon waste matrices may be biologically inaccessible to microbial communities and resistant to biotransformation. However, their very inaccessibility may, but not necessarily, also restrict the dose available to receptors. Clearly, attempts to improve the bioavailability of these components to microorganisms during bioremediation may also result in increased human exposure. In 
estimating the fate of pollutants in complex environmental matrices, the application of fugacity models ${ }^{52}$ for predicting the relative phase distributions and concentrations of contaminants and their metabolites during treatment ${ }^{75,76}$ is now proving valuable for informing exposure assessments and the optimisation of in-situ remediation. These approaches have yet to be applied to the biopiling of weathered oils or to account for the partitioning behaviour of PAH in weathered non-aqueous phase liquids (NAPL) within the unsaturated zone. In short, the relationships between chemical presence, toxic response, bioavailability and risk for weathered hydrocarbons have yet to be fully elucidated and coupled into a meaningful risk management framework, though work is progressing ${ }^{29-32,81}$. One of the obvious research needs is to authenticate human exposures to oil/soil matrices in the context of contaminated land and, in particular, to explore the bioavailability of riskcritical compounds (benzene, benzo[a]pyrene) in light of these newly revealed partition relationships.

The regulation of site remediation now requires adoption of a risk-based approach and this extends to technology verification ${ }^{29}$. Whereas the effectiveness of an environmental technology in treating pollution has historically been expressed as a percentage reduction in the pollutant concentration released to, or found in, a media of concern, regulators are increasingly concerned with mass, toxicity and risk reductions within the multimedia, multiphase environment. For petroleum hydrocarbons in soil, international regulatory guidance on the management of risks from contaminated sites is now emerging. As shown in this review, much of this guidance promotes the use of risk management frameworks to guide decision-making, the application of reference analytical methodologies and the derivation and use of acute, sub-chronic, and chronic toxicological criteria for these wastes. These frameworks adopt a variety of approaches to the evaluation of risk-critical components within the hydrocarbon waste-soil matrix. 
In the US, a substantive research effort has focused on integrating hydrocarbon fate and transport, petroleum microbiology and environmental diagnostics to inform regulatory processes for site management under the Superfund Program. ThermoRetec $(2000)^{81}$, reporting for the Petroleum Environmental Research Forum (PERF), provide an authoritative account of the central importance of partitioning within soil-bound hydrocarbons in developing environmentally acceptable endpoints (remedial objectives). Drawing on a detailed understanding of NAPL and residual oil fate and behaviour, this work is now influencing the development of remediation criteria for petroleum hydrocarbon in soils in the US for human health, groundwater and ecological receptors, and a reappraisal of the level of residual petroleum hydrocarbons that can be left at remediated sites without posing an unacceptable risk. In contrast, weathered, mid-distillate and heavier oil sources are generally given a narrow treatment by these reviews and frameworks. The Environment Agency $(2003)^{30}$ have recognised this in their recent consultation on principles for evaluating the human health risks from petroleum hydrocarbons in soils, and have called for views. One of the few environmental exposure assessments explicitly to address heavy oils has been discussed in a recent article relating to worker and visitor exposure following the wrecking of the oil tanker 'Erika' in $65 \mathrm{~km}$ south of the Brittany coast ${ }^{7}$. Here, inhalation, dermal and oral PAH exposures from beached No. 6 fuel oil were estimated and found to be negligible for beach cleaners and tourists (occasional visitors) coming into to contact with heavy oil, demonstrating the feasibility of this level of risk analysis for these problematical wastes.

The move towards risk-based corrective action (RBCA) has been slow in the UK and, whilst some progress has been made in integrating the aspects of analysis, exposure assessment and technology verification ${ }^{29}$, there are gaps in the current knowledge base. Specifically: (i) analytical strategies in the UK are not generally targeted at the bioavailability of risk-critical components; (ii) risk assessments do not regularly account for 
highly weathered residues encountered at many sites (API, 2001); and (iii) treatment 'success' is still supported by reductions in hydrocarbon load in isolation of combined reductions in toxicity, chemical mass and risk. In a typical study, Al Awadhi et al. (1996) ${ }^{2}$ report an $80 \% \mathrm{w} / \mathrm{w}$ reduction in oil from heavy oil-laden landfarming plots in Kuwait over a 15 month research period and Milne et al. (1998) between $30-50 \%$ w/w reductions in TPH from heavy refinery sludge treated in amended composting plots over the treatment period. Guerin $(2000)^{39}$ reports a 5 -year performance study of a land treatment facility for oil wastes from heavy vehicle maintenance. Most of these studies and many of those since (e.g. Tien et al., (1999) ${ }^{82}$ and Owens and Bourgouin, $(2003)^{67}$ ) follow a pattern of reporting reductions in TPH load as a presumed surrogate for risk reduction.

A contributing factor to the over-reliance on TPH as an indicator of treatment performance in isolation of other parameters, has been the cost of implementing more sophisticated diagnostic techniques and their low uptake within the sector. This has been, in part, as result of the absence of a regulatory framework. Nevertheless, researchers have been concerned with improved diagnostics methods (the analysis of specific carbon number ranges); the fingerprinting of hydrocarbon wastes for source identification (for liability disputes) and in tracking biotransformation; and with biological techniques as indicators of the impact of hydrocarbon contamination on soil function. Recent initiatives have included the development of reference methods for the analysis of petroleum hydrocarbons from $n \mathrm{C}_{6^{-}}$ $\mathrm{C}_{50}{ }^{19,83}$, the application of biomarker analysis ( $n$-alkane: substituted $n$-hopane indices) to bioremediation verification $^{45,61,100}$ and the validation of microbial bioassays for petroleum hydrocarbons in soil ${ }^{24,68}$. Our own work ${ }^{69}$, building on that of Prince et al. $(1994)^{72}$ demonstrated that the ratio of total alkanes ( $\sum n$-alkanes) to $17 \alpha(\mathrm{H}) 21 \beta(\mathrm{H})$-hopane to be the most sensitive of a series of biomarker ratios in reflecting oily waste depletion in a 256-day soil microcosm study. 


\section{CONCLUSIONS}

Risk assessment is a well-established paradigm for the management of contaminated land ${ }^{4}$. However, the move towards risk-based corrective action has been slow. Recent stakeholder consultations in the UK, and subsequent publications from the Environment Agency, aim to adopt a risk-based framework where remediation success is expressed in terms of risk rather than TPH load reductions.

There are several risk assessment frameworks for land contaminated with petroleum hydrocarbons including those published by TPHCWG ${ }^{88}$, ASTM $^{5}$, MADEP ${ }^{55}$, Environment Agency ${ }^{32}, \mathrm{API}^{3}$ and $\mathrm{CCME}^{18}$. However, none of these specifically deal with weathered petroleum hydrocarbons, which are widely acknowledged to have major qualitative and quantitative differences compared to non-weathered petroleum hydrocarbons ${ }^{87}$. Additionally, there are variations between frameworks that may result in different recommendations e.g. the level of remediation to be achieved. As shown, the use in some frameworks of deriving equivalent carbon numbers from empirical relationships representative of normalisation to the $n$-alkanes appears to be incorrect. In general, variations between frameworks occur in the determination of the range used, how toxicity is assessed and how soil samples are analysed.

Beyond the regulatory perspective, researchers have been involved in improving diagnostics methods (the analysis of specific carbon number ranges); the fingerprinting of hydrocarbon wastes for source identification (for liability disputes) and in tracking biotransformation; and with biological techniques as indicators of the impact of hydrocarbon contamination on soil function. There has also been increased interest in the use of fugacity 
models for making inferences about the fate and transport of risk-critical compounds within contaminated soils.

Many of these advances have yet to be synthesised into regulatory tools. However, there is growing support for the move towards compound-specific risk-based approaches for the assessment of hydrocarbon-contaminated land.

Acknowledgments - This work is funded under a Department of Trade and Industry-

Research Council Bioremediation LINK Grant and supported by a consortium of industrial partners (PROMISE). KJB is funded by an EPSRC CASE Award supported by the FIRSTFARADAY partnership. RLH is supported by BBSRC Grant BB/B512432/1 and is a Cranfield University Academic Fellow. The views expressed are the authors' alone.

\section{REFERENCES}

1. AEHS, Characterization of C6-C35 Petroleum Hydrocarbons in Environmental Samples - The Direct Method., Available at: http://www.aehs.com/publications/catalog/contents/Direct\%20Method.PDF (October 2004), 2000.

2. Al-Awadhi, N. , Al-Daher, R., ElNawawy, A., and Balba, M. T., Bioremediation of Oil-Contaminated Soil in Kuwait, J. Soil Contam., Vol. 5, No. 3, pp. 243-260, 1996.

3. API, Risk-based Methodologies for Evaluating Petroleum Hydrocarbon Impacts at Oil and Natural Gas E\&P Sites, API Publication 4709, Regulatory and Scientific Affairs Department American Petroleum Institute Publishing Services, Washington, DC, 2001.

4. ARCADIS Geraghty \& Miller International Inc., Risk Assessment Comparison Study, 916830024, NICOLE/ISG, 2004 
5. ASTM, Emergency Standard Guide for Risk-Based Corrective Action Applied at Petroleum Release Sites, ES 48-94, ASTM, Philadelphia, 1994.

6. ATSDR, Toxicological Profile for Total Petroleum Hydrocarbons (TPH), U.S. Department of Health and Human Services, Agency for Toxic Substances and Disease Registry, Atlanta, Georgia, 1999.

7. Baars, B.-J., The Wreckage of the Oil Tanker 'Ericka' - Human Heath Risk Assessment of Beach Cleaning, Sunbathing and Swimming, Toxicol. Lett., Vol. 128, pp. 55-68, 2002.

8. Barakat, A. O., Mostafa, A. R., Qian, Y., and Kennicutt, M. C., Application of Petroleum Hydrocarbon Chemical Fingerprinting in Oil Spill Investigations - Gulf of Suez, Egypt, Spill Sci. Technol. B., Vol. 7, No. 5-6, pp. 229-239, 2002.

9. Barakat, A. O., Qian, Y., Kim, M., and Kennicutt, M. C., Chemical Characterisation of Naturally Weathered Oil Residues in Arid Terrestrial Environment in Al-Alamein, Egypt, Environ. Int., Vol. 27, pp. 291-310, 2001.

10. Barrs, A. J., Theelen, R. M. C., Janssen, P. J. C. M., Hesse, J. M., van Apeldoorn, M. E., Meijerink, M. C. M., Verdam, L., and Zeilmaker, M. J., Re-evaluation of humantoxicological maximum permissible risk levels, RIVM Report 711701 025, RIVM, Netherlands, 2001.

11. BATTELLE, Biopile design and construction manual, Technical Memorandum TM2189-ENV, NFESC, California, 1996.

12. Bhupathiraju, V. K., Krauter, P., Holman, H.-Y. N., Conrad, M. E., Daley, P. F., Templeton, A. S., Hunt, J. R., Hernandez, M., and Alvarez-Cohen, L., Assessment of in-Situ Bioremediation at a Refinery Waste Contaminated Site and an Aviation Gasoline Contaminated Site, Biodegradation, Vol. 13, pp. 79-90, 2002.

13. BIOWISE, Contaminated Land remediation - A Review of Biological Technology, 
DTI, Oxon, UK, 2000.

14. Boehm, P. D. , Douglas, G. S., Burns, W. A., Mankiewicz, P. J., Page, D. S., and Bence, A. E., Application of Petroleum Hydrocarbon Chemical Fingerprinting and Allocation Techniques After the Exxon Valdez Oil Spill, Mar. Pollut. Bull., Vol. 34, No. 8, pp. 599-613, 1997.

15. Buco, S., Moragues, M., Doumenq, P., Noor, A., and Mille, G., Analysis of Polycyclic Aromatic Hydrocarbons in Contaminated Soil by Curie Point Pyrolysis Coupled to Gas Chromatography-Mass Spectrometry, an Alternative to Conventional Methods., J. Chromatogr. A, Vol. 1026, pp. 223-229, 2004.

16. Buddhadasa, S. C., Barone, S., Bigger, S. W., and Orbell, J. D., Australian Approaches to Improving Methods for the Analysis of TPH Contamination in Soil, in 17th WCSS at Thailand, 2002.

17. CCME, Canada-Wide Standards for Petroleum Hydrocarbons (PHCs) in Soil: Scientific Rationale, CCME, Winnipeg, Manitoba, Canada, 2000.

18. CCME, Canada-Wide Standards for Petroleum Hydrocarbons (PHCs) in Soil: Technical Supplement, CCME, Winnipeg, Manitoba, Canada, 2001.

19. CCME, Reference methods for the Canada-wide standard for petroleum hydrocarbons in soil - Tier 1 Method., Publication No. 1310, CCME, Winnipeg, Manitoba, Canada, 2001.

20. Cookson, J. T. J., Bioremediation Engineering: Design and Application, McGrawHill, New York, 1995.

21. Coulon, F., Pelletier, E., Gourhant, L., and Delille, D., Effects of Nutrient and Temperature on Degradation of Petroleum Hydrocarbons in Contaminated SubAntartic Soil, Chemosphere, Vol. 58, pp. 1439-1448, 2005.

22. Dean, J. A., Analytical Chemistry Handbook, McGraw-Hill, New York, 1995 
23. DETR, Contaminated Land: Implementation of Part IIA of the Environmental Protection Act 1990, DETR Circular 2/2000, 2000.

24. Dorn, P. B. and Salinitro, J. P., 'Temporal Ecological Assessment of Oil Contaminated Soils Before and After Bioremediation', Chemosphere, Vol. 40, No. 4, pp. 419-426, 2000.

25. DTI, Biological Methods for Contaminated Land Management, available at: http://www.biowise.org.uk/core_files/Ciria\%20publication.pdf (accessed 2004), 2003.

26. Ellis, B., Reclaiming Contaminated Land: In Situ/Ex Situ Remediation of Creosoteand Petroleum Hydrocarbon-Contaminated Sites, in Bioremediation Field Experience, Lewis Publishers, United States, pp. 107-143, 1994.

27. Environment Agency, Survey of remedial techniques for land contamination in England and Wales, R \& D Technical Report P401, Environment Agency, Almondsbury, Bristol, 2000.

28. Environment Agency, Remedial Treatment Action Data Sheets, Agency Management Systems Document: Data Sheet No. DS-01, Environment Agency, 2002.

29. Environment Agency, Model procedures for the management of land contamination (CLR11) Version 2v2, Environment Agency, Solihull, 2003.

30. Environment Agency, Principles for Evaluating the Human Health Risks from Petroleum Hydrocarbons in Soils: A consultation Paper, R \& D Technical Report P5080/TR1, Environment Agency, Almondsbury, Bristol, 2003.

31. Environment Agency, Review of Comments on: Environment Agency Public Consultation Paper - Principles for Evaluating the Human Health Risks from Petroleum Hydrocarbons in Soils, Science Report P5-080/TR2, Environment Agency, Almondsbury, Bristol, 2004.

32. Environment Agency, The UK Approach for Evaluating Human Health Risks from 
Petroleum Hydrocarbons in Soils, Science Report P5-080/TR3, Environment Agency, Almondsbury, Bristol, 2005.

33. Eweis, J. B. , Ergas, S. J., Chang, D. P. Y., and Schroeder, E. D., Bioremediation Principles, McGraw-Hill, Boston, 1998.

34. Farrell-Jones, J., 'Petroleum Hydrocarbons and Polyaromatic Hydrocarbons', in Thompson, C. K. and Nathanail, P. C., Chemical Analysis of Contaminated Land, Blackwell, Oxford, pp. 132-176, 2003.

35. Ferguson, C. C., Assessing the Risks from Contaminated Land Sites: Policy and Practice in 16 European Countries, Land Contamination and Reclamation, Vol. 7, No. 2, pp. 33-54, 1999.

36. Flathman, P. E., Jerger, D. E., and Exner, J. H., Bioremediation Field Experience, Lewis Publishers, United States, 1994.

37. Fogel, S., Full-Scale Bioremediation of No. 6 Fuel Oil-Contaminated Soil: 6 Months of Active and 3 Years of Passive Treatment, in Bioremediation Field Experience, Lewis Publishers, United States, pp. 161-175, 1994.

38. Frysinger, G. S., Gaines, R. B., Xu, L., and Reddy, C. M., Resolving the Unresolved Complex Mixture in Petroleum-Contaminated Sediments, Environ. Sci. Techol., Vol. 37, pp. 1653-1662, 2003.

39. Giles, W. R. JR., Kriel, K. D., and Stewart, J. R., Characterization and Bioremediation of a Weathered Oil Sludge, Environmental Geosciences, Vol. 8, No. 2, pp. 110-122, 2001.

40. Guerin, T. F., Long-Term Performance of a Land Treatment Facility for the Bioremediation of Non-Volatile Oil Wastes, Resour. Conserv. Recy., Vol. 28, pp. 105-120, 2000.

41. Harries, N., Doherty, M., and Sweeney, R., Biopile Field Demonstration at the 
Avenue Coking Works, CL:AIRE Demonstration Project Report: TDP6, Contaminated Land: Application in Real Environments (CL:AIRE), London, 2004.

42. Hawthorne, S. B., Grabanski, C. B., Martin, E., and Miller, D. J., Comparisons of Soxhlet Extraction, Pressurized Liquid Extraction, Supercritical Fluid Extraction and Subcritical Water Extraction for Environmental Solids: Recovery, Selectivity and Effects on Sample Matrix., J. Chromatogr. A, Vol. 892, pp. 421-433, 2000.

43. Hejazi, R. F., Husain, T., and Khan, F. I., Landfarming Operation of Oily Sludge in Arid Region Human Health Risk Assessment , J. Hazard. Mater. B, Vol. 99, pp. 287302, 2003.

44. Holgate, G., The New Contaminated Land Regime: Part IIA of the Environmental Protection Act 1990, Land Contamination and Reclamation, Vol. 8, pp. 117-132, 2000.

45. Hollender, J., Koch, B., Lutermann, C., and Dott, W., Efficiency of Different Methods and Solvents for the Extraction of Polycyclic Aromatic Hydrocarbons from Soils, Intern. J. Environ. Anal. Chem., Vol. 83, No1, pp. 21-32, 2003. 46. Hough, R. L., Whittaker, M., Fallick, E., Preston, T., Farmer, J. G., and Pollard, S. J. T., Identifying Source Correlation Parameters for Hydrocarbon Wastes Using Compound-Specific Isotope Analysis, Environ. Pollut., In Press, 2006.

47. Howat, D. R., Frequently asked questions on the remediation and reclamation of soil and groundwater, Alberta Environment, Alberta, 2002.

48. Hutcheson, M. S., Pedersen, D., Anastas, N. D., Fitzgerald, J., and Silverman, D., Beyond TPH: Health-Based Evaluation of Petroleum Hydrocarbon Exposures, Regul. Toxicolo. Pharm., Vol. 24, pp. 85-101, 1996.

49. Hyman, M. and Dupont, R. R., Groundwater and Soil Remediation: Process Design and Cost Estimating of Proven Technologies, American Society of Civil Engineers, 
Virginia, 2001.

50. Jorgensen, K. S., Puustinen, J., and Suortti, A.-M., Bioremediation of Petroleum Hydrocarbon-Contaminated Soil by Composting in Biopiles, Environ. Pollut., Vol. 107 , pp. 245-254, 2000.

51. Kaplan, I. R., Galperin, Y., Alimi, H., Less, R.-P., and Lu, S.-T., Patterns of Chemical Changes During Environmental Alteration of Hydrocarbon Fuels', Ground Water Monit. R., Vol. 16, No. 4, pp. 113-124, 1996.

52. Kaufman, A. K., Selection of Bioremediation for Site Cleanup: Decision Factors, in Bioremediation Field Experience, Lewis Publishers, United States, pp. 51-58, 1994.

53. Mackay, D., Finding Fugacity Feasible, Environ. Sci. Technol., Vol. 13, No. 10, pp. 1218-1223, 1979.

54. MADEP, Interim Final Petroleum Report: Development of Health-based Alternative to the Total Petroleum Hydrocarbon (TPH) Parameter, Massachusetts Department of Environmental Protection, Executive Office of Environmental Affairs, Commonwealth of Massachusetts, Boston, MA, 1994.

55. MADEP, Draft Updated Petroleum Hydrocarbon Fraction Toxicity Values for the VEP/EPH/APH Methodology, Massachusetts Department of Environmental Protection, Executive Office of Environmental Affairs, Commonwealth of Massachusetts, Boston, MA, 2002.

56. MADEP, Characterizing Risks Posed by Petroleum Contaminated Sites: Implementation of the MADEP VEP/EPH Approach, Policy \#WSC-02-411, Policy \#WSC-02-411, Massachusetts Department of Environmental Protection, Executive Office of Environmental Affairs, Commonwealth of Massachusetts, Boston, MA, 2002.

57. MADEP, Method for the determination of extractable petroleum hydrocarbons 
$(E P H)$, Revision 1.1, Massachusetts Department of Environmental Protection, Executive Office of Environmental Affairs, Commonwealth of Massachusetts, Boston, MA, 2004

58. MADEP, Method for the determination of volatile petroleum hydrocarbons (VPH), Revision 1.1, Massachusetts Department of Environmental Protection, Executive Office of Environmental Affairs, Commonwealth of Massachusetts, Boston, 2004.

59. Margesin, R. and Schinner, F., Review Biological Decontamination of Oil Spills in Cold Environments, J. Chem. Technol. Biot., Vol. 74, pp. 381-389, 1999.

60. McMillen, S. J., Magaw, R. I., and Carovillano, R. L., Risk-Based Decision-Making for Assessing Petroleum Impacts at Exploration and Production, The Department of Energy and the Petroleum Environmental Research Forum, Tulsa, OK, 2001.

61. Ministry for the Environment, Guidelines for Assessing and Managing Petroleum Hydrocarbon Contaminated Sites in New Zealand, Ministry for the Environment, New Zealand, 1999.

62. Moldowan, J. M., Dahl, J., McCaffrey, M. A., Smith, W. J., and Fetzer, J. C., Application of Biological Marker Technology to Bioremediation of Refinery byProducts, Energ. Fuel., Vol. 9, No. 1, pp. 155-162, 1995.

63. Nathanail, P. C. and Bardos, P. R., Reclamation of Contaminated Land, John Wiley \& Sons, England, 2004.

64. National Environment Protection Council, Schedule B (3): Guideline on laboratory analysis of potentially contaminated soils, National Environment Protection Council, Available from: http://www.ephc.gov.au/pdf/cs/cs_03_lab_analysis.pdf (accessed 01/07/05), 1999.

65. New South Wales Environment Protection Agency, Draft Guidelines for the Assessment of Former Gasworks Sites, New South Wales Environment Protection 
Agency, Sydney, 2003.

66. NICOLE, CLAIRNET/NICOLE Joint Statement: Better Decision Making Now, available at: www.nicole.org/publications/NICOLEjoint2.PDF (accessed 2005), 1998.

67. Oil Industry Environmental Working Group, Draft, sampling protocols and analytical methods for determining petroleum products in soil and water, Oil Industry

Environmental Working Group, Available from:

http://www.mfe.govt.nz/publications/hazardous/sampling-protocols-oil-may99.pdf (accessed 01/07/05), 1999.

68. Owens, J. and Bourgouin, C., Biological Treatment of Hydrocarbon Contaminated Soils for Channel Tunnel Rail Link Project, London, England, in ConSoil 2003, 8th International FZK/TNO Conference on Contaminated Soil in Ghent; FZK/TNO, Belgium, pp. 2157-2162, 2003.

69. Pollard, S. J. T., Hough, R. L., Brassington, K., Sinke, A., Crossley J, Paton, G. I., Semple, K., Risdon, G., Jackman S.J, Bone, B., Jacobsen, C., and Lethbridge G, Optimising the Biopiling of Weathered Hydrocarbons Within a Risk Management Framework - PROMISE, in CL:AIRE and FIRST FARADAY Joint Conference on Contaminated Land 27-28 $8^{\text {th }}$ April, 2005 at International Convention Centre, Birmingham, UK, 2005.

70. Pollard, S. J. T., Whittaker, M., and Risden, G. C., The Fate of Heavy Oil Wastes in Soil Microcosms I: a Performance Assessment of Biotransformation Indices, Sci. Total Environ., Vol. 226, pp. 1-22, 1999.

71. Pollard, S. J. T., Hrudey, S. E., and Fedorak, P. M., Bioremediation of Petroleum- and Creosote-Contaminated Soils: a Review of Constraints, Waste Manage. Res., Vol. 12, pp. 173-194, 1994.

72. Pollard, S. J. T., Hrudey, S. E., Rawluck, M., and Fuhr, B. J., Characterisation of 
Weathered Hydrocarbon Wastes at Contaminated Sites by GC-Simulated Distillation and Nitrous Oxide Chemical Ionisation GC-MS, With Implications for Bioremediation, J. Environ. Monitor., Vol. 6, pp. 713-718, 2004.

73. Prince, R. C., Elmendorf, D. L., Lute, J. R., Hsu, C. S., Haith, C. E., Senius, J. D., Dechert, G. J., Douglas, G. S., and Butler, E. L., $17 \alpha(\mathrm{H}), 21 \beta(\mathrm{H})$-Hopane As a Conserved Internal Marker for Estimating the Biodegradation of Crude Oil, Environ. Sci. Technol., Vol. 28, pp. 142-145, 1994.

74. Reid, B. J., Jones, K. C., and Semple, K. T., Bioavailability of Persistent Organic Pollutants in Soils and Sediments- a Perspective on Mechanisms, Consequences and Assessment, Environ. Pollut. , Vol. 108, pp. 103-112, 2000.

75. Saifuddin, N. and Chua, K. H., Extraction of Tetrachloroethylene From Weathered Soils: A Comparison Between Soxhlet Extraction and Microwave-Assisted Extraction, Malaysian Journal of Chemistry, Vol. 5, No. 1, pp. 030-033, 2003.

76. Sims, R. C., Subsurface Environment Fugacity Framework, TCE Case Study, available at: http://www.engineering.usu.edu/uwrl/fugacity/fugacity.html (accessed 2003), 2003.

77. Sims, R. C. and Sims, J. L., Chemical Mass Balance Approach to Field-Scale Evaluation of Bioremediation, Environ. Prog., Vol. 14, No. 1, pp. F2-3, 1995.

78. Sims, R. C., Soil Remediation Techniques at Uncontrolled Hazardous Waste Sites: A Critical Review, J. Air Waste Manage., Vol. 40, No. 5, pp. 704-732, 1990.

79. Sun, S. B. and Boyd, S. A., Sorption of Polychlorobiphenyl (PCB) Congeners by Residual PCB-Oil Phases in Soils, J. Environ. Qual., Vol. 20, No. 3, pp. 557-561, 1991.

80. Swannell, R. P. J., Croft, B. C., Grant, A. L., and Lee, K., Evaluation of Bioremediation Agents in Beach Microcosms, Spill Sci. Technol. B., Vol. 2, No. 2/3, 
pp. 151-159, 1995.

81. The Council of the European Union, Council Directive 1999/31/EC of 26 April 1999 on the Landfill of Waste, Official Journal of the European Communities, 1999.

82. ThermoRetec Consulting Corporation, Environmentally Acceptable Endpoints for Hydrocarbon-contaminated Soils, Prepared for Petroleum Environmental Research Forum Project 94-06 (Research Area 1), 2000.

83. Tien, A. J., Altman, D. J., Worsztynowicz, A., Zacharz, K. , Ulfig, K., Manko, T., and Hazen, T. C., Bioremediation of a Process Water Lagoon at a Southern Polish Oil Refinery - DOE's First Demonstration Project in Poland, in Fourth International Symposium and Exhibition on Environmental Contamination in Central and Eastern Europe (Warsaw '98) at Institute for International Cooperative Environmental Research at the Florida State University; Florida State University, USA, 1999.

84. TNRCC, Total Petroleum Hydrocarbons, TNRCC Method 1005, Revision 03, Revision 03, Texas Natural Resource Conservation Commission, Austin, Texas, 2001.

85. TPHCWG, Total Petroleum Hydrocarbon Criteria Working Group Series Volume 3: Selection of Representative TPH Fractions Based on Fate and Transport Considerations., Amherst Scientific, Amherst, Massachusetts, 1997.

86. TPHCWG, Total Petroleum Hydrocarbon Criteria Working Group Series Volume 4: Development If Fraction Specific Reference Doses (RfDs) and Reference Concentrations (RfCs) for Total Petroleum Hydrocarbons (TPH), Amherst Scientific, Amherst, Massachusetts, 1997.

87. TPHCWG, Total Petroleum Hydrocarbon Criteria Working Group Series Volume 1: Analysis of Petroleum Hydrocarbons in Environmental Media, Amherst Scientific, Amherst, Massachusetts, 1998.

88. TPHCWG, Total Petroleum Hydrocarbon Criteria Working Group Series Volume 2: 

1998.

89. TPHCWG, Total Petroleum Hydrocarbon Criteria Working Group Series Volume 5: Human Health Risk-Based Evaluation of Petroleum Release Sites: Implementing the Working Group Approach, Amherst Scientific, Amherst, Massachusetts, 1999.

90. Trindade, P. V. O., Sobral, L. G., Rizzo, A. C. L., Leite, S. G. F., and Soriano, A. U., Bioremediation of a Weathered and a Recently Oil-Contaminated Soils From Brazil: a Comparison Study, Chemosphere, Vol. 58, No. 4, pp. 515-522, 2005.

91. USEPA, Method 3541 - Automated Soxhlet extraction, USEPA, USA, 1994.

92. USEPA, Method 3500B - Organic extraction and sample preparation, USEPA, USA, 1996.

93. USEPA, Method 3540C - Soxhlet Extraction, USEPA, USA, 1996.

94. USEPA, Method 3545 - Pressurised fluid extraction (PFE), USEPA, USA, 1996.

95. USEPA, Method 3550B - Ultrasonic extraction, USEPA, USA, 1996.

96. USEPA, Method 3546 - Microwave extraction, USEPA, USA, 2000.

97. USEPA, Method 3570 - Microscale solvent extraction, USEPA, USA, 2002.

98. USEPA, Method 3611B - Alumina column cleanup and separation of petroleum wastes, USEPA, USA, 1996.

99. USEPA, SW-846 On-Line, available at: http://www.epa.gov/epaoswer/hazwaste/test/main.htm (accessed 2005), 2005.

100. Vegter, J., Lowe, J., and Kasamas, H., Sustainable Management of Contaminated Land: An Overview, Austrian Federal Environment Agency, on behalf of CLARINET, Austria, 2002.

101. Vegter, J. J., 'Sustainable Contaminated Land Management: a Risk-Based Land Management Approach', Land Cont. Rec., Vol. 9, No. 1, pp. 95-100, 2001. 
102. Vik, E. A., Bardos, P., Brogan, J., Edwards, D., Gondi, F., Henrysson, T., Jensen, B. K., Jorge, C., Mariotti, C., Nathanail, P., and Papassiopi, N., 'Towards a Framework for Selecting Remediation Technologies for Contaminated Sites', Land Cont. Rec., Vol. 9, No. 1, pp. 119-127, 2001.

103. Wang, Z. and Fingas, M., 'Differentiation of the Source of Spilled Oil and Monitoring of the Oil Weathering Process Using Gas Chromatography-Mass Spectrometry', $J$. Chromatogr. A, Vol. 712, pp. 321-343, 1995.

104. Wang, Z., Fingas, M., Landriault, M., Sigouin, L., Feng, Y., and Mullin, J.,'Using Systematic and Comparative Analytical Data to Identify the Source of an Unknown Oil on Contaminated Birds, J. Chromatogr. A, Vol. 775, pp. 251-265, 1997.

105. Wang, Z., Fingas, M., and Page, D. S., Oil Spill Identification, J. Chromatogr. A, Vol. 843, pp. 369-411, 1999.

106. Wang, Z., Fingas, M., and Sergy, G., Chemical Characterisation of Crude Oil Residues From an Artic Beach by GC/MS and GC/FID, Environ. Sci. Technol., Vol. 29, pp. 2622-2631, 1995.

107. Wang, Z. and Fingas, M. F., Development of Oil Hydrocarbon Fingerprinting and Identification Techniques, Mar. Pollut. Bull., Vol. 47, pp. 423-452, 2003.

108. Whittaker, M., Pollard, S. T. J., and Risden, G., The Fate of Heavy Oil Wastes in Soil Microcosms II: a Performance Assessment of Source Correlation Indices, Sci. Total Environ., Vol. 226, pp. 23-34, 1999.

109. Whittaker, M., Pollard, S. J. T., and Fallick, T. E., Characterisation of Refractory Wastes at Heavy Oil-Contaminated Sites: a Review of Conventional and Novel Analytical Methods, Environ. Technol., Vol. 16, pp. 1009-1033, 1995.

110. Wood, P., Remediation Methods for Contaminated Sites, in, Assessment and Reclamation of Contaminated Land, The Royal Society of Chemistry, Cambridge, pp. 
115-139, 2001.

111. Wood, P. A., Remediation Methods for Contaminated Sites, in Issues in Environmental Science and Technology: Contaminated Land and Its Reclamation, The Royal Society of Chemistry, Cambridge, pp. 47-71, 1997.

112. Woolgar, P. J. and Jones, K. C., Studies on the Dissolution of Polycyclic Aromatic Hydrocarbons From Contaminated Materials Using a Novel Dialysis Tubing Experimental Method, Environ. Sci. Technol., Vol. 33, pp. 2118-2126, 1999.

113. Xu, R., Lau, A. N. L., Lim, Y. G., and Obbard, J. P., Bioremediation of OilContaminated Sediments on a Inter-Tidal Shoreline Using a Slow-Release Fertiliser and Chitosan, Mar. Pollut. Bull., Vol. 51, pp. 1062-1070, 2005.

114. Xu, R., Yong, L. C., Lim, Y. G., and Obbard, J. P., Use of Slow-Release Fertilizer and Biopolymers for Stimulating Hydrocarbon Biodegradation in Oil-Contaminated Beach Sediments, Mar. Pollut. Bull., Vol. 51, pp. 1101-1110, 2005.

115. Zemanek, M. G., Pollard, S. J. T., Kenefick, S. L., and Hrudey, S. E., Multi-Phase Partitioning and Co-Solvent Effects for Polynuclear Aromatic Hydrocarbons (PAH) in Authentic Petroleum- and Creosote-Contaminated Soils, Environ. Pollut., Vol. 98, No. 2, pp. 239-252, 1997. 
Figure 1: General petroleum hydrocarbon degradation pattern (modified after Kaplan et al., $\left.(1996)^{50}\right)$

Abundant $n$-alkanes

Light end $n$-alkanes

Middle range $n$-alkanes, olefins, benzene and toluene removed

More than $90 \%$ of $n$-alkanes

Alkylcyclohexanes and alkylbenzens removed; isoprenoids and $\mathrm{C}_{0^{-}}$ naphthalene reduced

Isoprenoids, $\mathrm{C}_{1}$-naphthalenes, benzoethiphene and alkylbenzothiophenes removed $\mathrm{C}_{2}$-naphthalenes selectively reduced

Phenathrenes, dibenzothiphenes and other polynuclear aromatic hydrocarbons reduced

Tricyclic terpanes enriched, regular steranes selectively removed, $\mathrm{C}_{31}$ to $\mathrm{C}_{35}$-homohopanes reduced

Tricyclic terpanes, disateranes and aromatic steranes abundant

Aromatic steranes and demethylated hopanes* predominate.

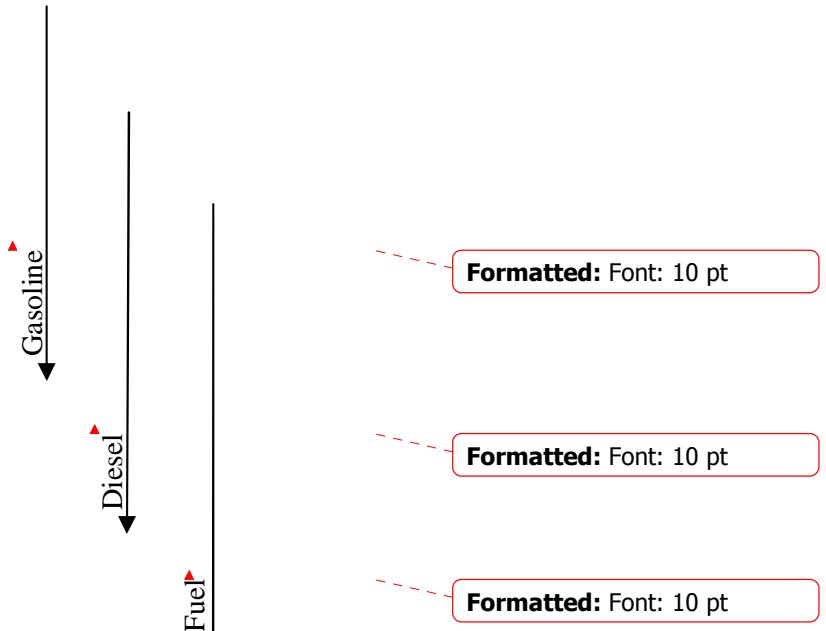

1098

* Present under special conditions only.

1099

1100

110

1102

1103

1104

1105

1106

1107 
Figure 2: Illustration of the interactions of the key elements involved in remediation of weathered petroleum hydrocarbon contaminated land.

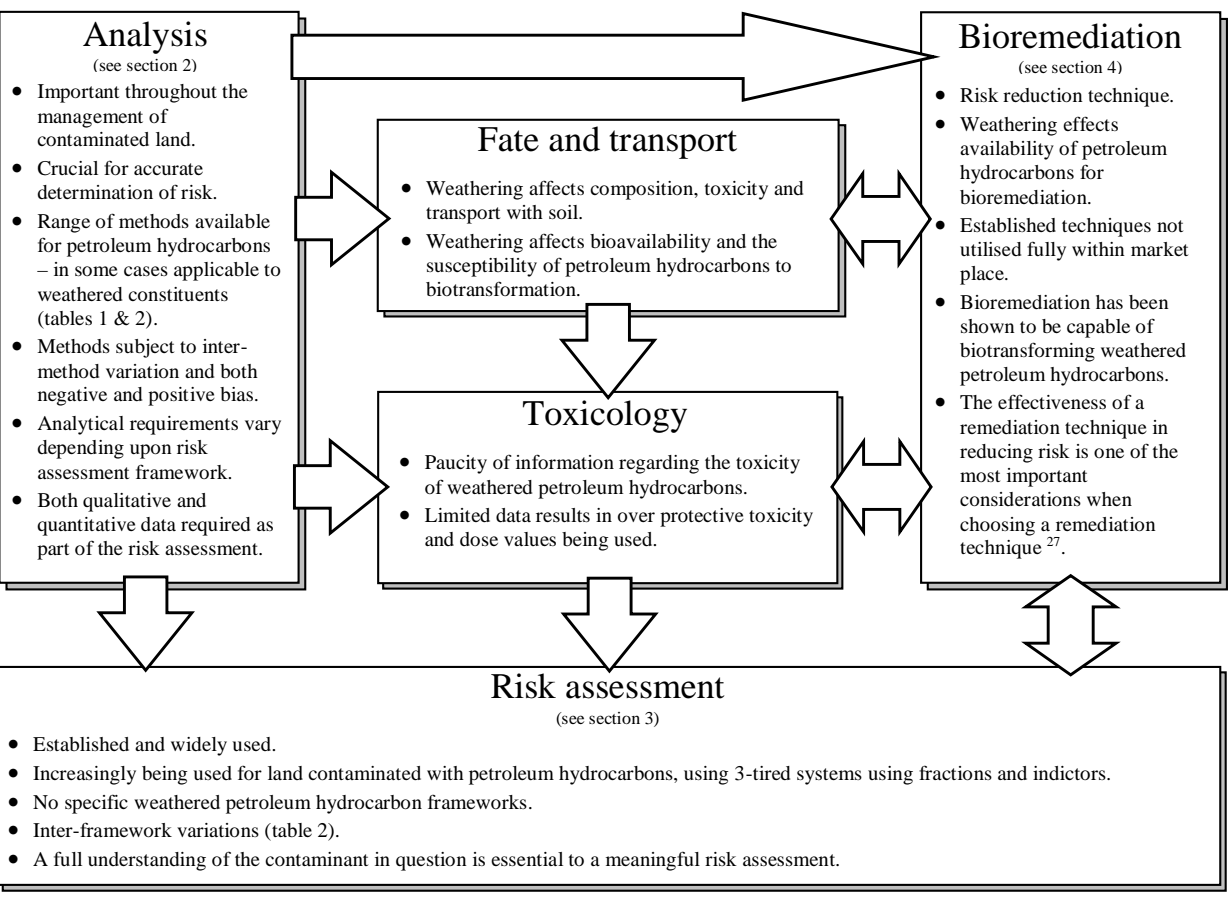

- Inter-framework variations (table 2).

- A full understanding of the contaminant in question is essential to a meaningful risk assessment. 


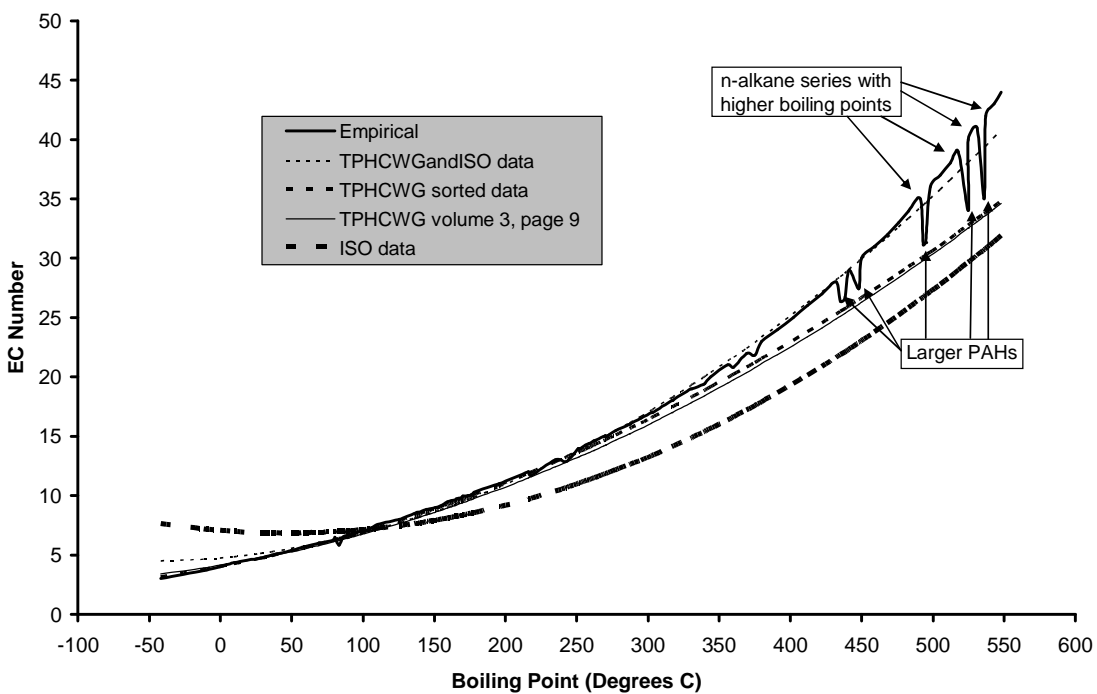




\begin{tabular}{|c|c|c|c|c|c|}
\hline & $\begin{array}{l}\text { Massachusetts Department of } \\
\text { Environmental Protection }{ }^{54}\end{array}$ & $\begin{array}{l}\text { Total Petroleum Hydrocarbon } \\
\text { Criteria Working Group }{ }^{85-89}\end{array}$ & $\begin{array}{l}\text { Canadian Council of Ministers } \\
\text { of the Environment }{ }^{118}\end{array}$ & New Zealand $^{61}$ & New South Wales ${ }^{64}$ \\
\hline Description & $\begin{array}{l}\text { Use of two methods. Volatile } \\
\text { petroleum hydrocarbon (VPH) } \\
\text { method }^{57} \text { and extractable } \\
\text { petroleum hydrocarbon (EPH) } \\
\text { method }^{56} \text { developed by MaDEP. } \\
\text { The EPH method refers to } \\
\text { USEPA methods for sample } \\
\text { extraction } \\
57,98 \text {. }\end{array}$ & $\begin{array}{l}\text { Use of 'The Direct method' } \\
\text { (AEHS) }{ }^{1} \text { developed for the } \\
\text { TPHCWG framework. Based } \\
\text { upon USEPA SW-864 test } \\
\text { methods }^{97} \text { and MaDEP EPH } \\
\text { method }^{5}\end{array}$ & $\begin{array}{l}\text { Recommends the use of } \\
\text { benchmarked methods }{ }^{19} \text {, } \\
\text { however also allows the use of } \\
\text { non-benchmarked methods } \\
\text { providing that validation data } \\
\text { demonstrate that the substitute } \\
\text { method provides data } \\
\text { comparable to the benchmark } \\
\text { method. }\end{array}$ & $\begin{array}{l}\text { Permits the use of a variety of } \\
\text { methods, including those } \\
\text { prepared by the Oil Industry } \\
\text { Environmental Working Group } \\
(1999)^{67} \text { which outlines methods } \\
\text { for several different petroleum } \\
\text { products often referring the } \\
\text { reader to USEPA } \\
\text { documentation }^{67,99} \text {. }\end{array}$ & $\begin{array}{l}\text { Recommends the use of } \\
\text { methods specified in the } \\
\text { National Environmental } \\
\text { Protection Councils (NEPC) } \\
\text { Schedule } \\
\text { B(3): Guideline on Laboratory } \\
\text { Analysis of Potentially } \\
\text { Contaminated Soils (1999) } \\
\text { Where no suitable analytical } \\
\text { method is available it } \\
\text { recommends the use of } \\
\text { USEPA }^{97} \text {., or equivalent } \\
\text { methods } \\
\text { should be call chemical analysis } \\
\text { laboratories in } \\
\text { by the national astly accredited } \\
\text { testing authorities (NATA). }\end{array}$ \\
\hline $\begin{array}{l}\text { Reported } \\
\text { Range }\end{array}$ & $\mathrm{C}_{5}$ to $\mathrm{C}_{36}$ & $\mathrm{C}_{6}$ to $\mathrm{C}_{35}$ & $\mathrm{C}_{6}$ to $\mathrm{C}_{50}$ & $\mathrm{C}_{6}$ to $\mathrm{C}_{36}$ & $\mathrm{C}_{7}$ to $\mathrm{C}_{36}$ \\
\hline $\begin{array}{l}\text { Sample } \\
\text { collection }\end{array}$ & $\begin{array}{l}\text { EPH method uses amber glass } \\
\text { wide mouth sample jars with } \\
\text { Teflon lined screw caps. These } \\
\text { are cooled immediately after } \\
\text { collection and extracted within } \\
\text { 14days of receiving the sample. } \\
\text { VPH method uses specially } \\
\text { designed air tight collection } \\
\text { vials with Teflon-lined septa } \\
\text { screw caps stored at } 4^{\circ} \mathrm{C} \text { and } \\
\text { preserved with methanol before } \\
\text { analysis within a maximum of } \\
28 \text { days. }\end{array}$ & $\begin{array}{l}\text { Wide mouth glass jars with } \\
\text { Teflon lined caps stored at } 4^{\circ} \mathrm{C} \text {. } \\
\text { Analysis must be performed } \\
\text { within } 14 \text { days of sample } \\
\text { collection. }\end{array}$ & $\begin{array}{l}\text { Wide mouth glass jars with } \\
\text { aluminium foil or Teflon-lined } \\
\text { lids. Samples must completely } \\
\text { fill the jars. Samples are not } \\
\text { chemically preserved but are } \\
\text { cooled to } 4^{\circ} \mathrm{C} \text {. Laboratory } \\
\text { sample handling procedure is } \\
\text { also outlined. }\end{array}$ & $\begin{array}{l}\text { 100ml (volatiles) and } 250 \mathrm{ml} \\
\text { (semi-volatiles) Borosilicate jars } \\
\text { with Teflon-lined cap and } \\
\text { completely filled. Stored at } 4^{\circ} \mathrm{C} \\
\text { in the dark. }\end{array}$ & $\begin{array}{l}\text { Use of USEPA }{ }^{97} \text { or equivalent } \\
\text { methods }\end{array}$ \\
\hline
\end{tabular}

1141 


\begin{tabular}{|c|c|c|c|c|c|}
\hline & $\begin{array}{l}\text { Massachusetts Department of } \\
\text { Environmental Protection }\end{array}$ & $\begin{array}{l}\text { Total Petroleum Hydrocarbon } \\
\text { Criteria Working Group }\end{array}$ & $\begin{array}{l}\text { Canadian Council of Ministers } \\
\text { of the Environment }{ }^{18}\end{array}$ & New Zealand & New South Wales \\
\hline $\begin{array}{l}\text { Extraction } \\
\text { technique }\end{array}$ & $\begin{array}{l}\text { VPH method uses Purge and } \\
\text { trap with methanol. } \\
\\
\text { EPH method uses DCM for } \\
\text { extraction and solvent } \\
\text { exchanges into hexane. Using } \\
\text { USEPA methods } 3540 \mathrm{C}^{92} \\
\text { (Soxhlet), 3545 } \mathrm{A}^{93} \text { (pressurised } \\
\text { fluid extraction (PFE)), } 3541^{90} \\
\text { (Automated Soxhlet extraction), } \\
3546^{95} \text { (Microwave extraction) } \\
\text { and } 3570^{96} \text { (microscale solvent } \\
\text { extraction (MSE)). }\end{array}$ & $\begin{array}{l}\text { Vortex or shaker method using } \\
n \text {-pentane. }\end{array}$ & $\begin{array}{l}\text { Purge and trap for } C_{6} \text { to } C_{10} \\
\text { range using methanol. Soxhlet is } \\
\text { the benchmarked method for the } \\
C_{10} \text { to } C_{50} \text { range. }\end{array}$ & $\begin{array}{l}\text { For the } C_{10} \text { to } C_{36} \text { range any } \\
\text { method that can be } \\
\text { demonstrated to meet the } \\
\text { performance criteria can be } \\
\text { used. For the } C_{6} \text { to } C_{9} \text { range } \\
\text { purge and trap is used. }\end{array}$ & $\begin{array}{l}\text { USEPA methods } 3540 \mathrm{~B}^{97} \text { or } \mathrm{C}^{92} \\
\text { (Soxhlet extraction), 35500B } \\
\text { (sonication extraction) or } \\
\text { sequential bath sonication and } \\
\text { agitation described by } \mathrm{NEPC}^{63} \text {. }\end{array}$ \\
\hline Evaporation & $\begin{array}{l}\text { The EPH method uses those } \\
\text { specified by the USEPA. } \\
\text { However, after fractionation the } \\
\text { use of gentle stream of air or } \\
\text { nitrogen is recommended to } \\
\text { bring the sample to the required } \\
\text { volume. } \\
\text { Evaporation is not applicable to } \\
\text { the VPH method. }\end{array}$ & N/A & $\begin{array}{l}\text { Uses an evaporation vessel after } \\
\text { extraction for the } C_{10} \text { to } C_{50} \\
\text { range. After silica gel cleanup } \\
\text { rotary evaporator is the } \\
\text { benchmarked method to reach } \\
\text { the required sample volume. }\end{array}$ & $\begin{array}{l}\text { Permits the use of any method } \\
\text { that can be demonstrated to } \\
\text { meet the performance criteria. }\end{array}$ & $\begin{array}{l}\text { USEPA methods specified for } \\
\text { extraction using Kurderna- } \\
\text { Danish (K-D) evaporation. }\end{array}$ \\
\hline $\begin{array}{l}\text { Clean up } \\
\text { /fractionation }\end{array}$ & $\begin{array}{l}\text { Silica gel clean up for EPH } \\
\text { method. } \\
\text { Not applicable to VPH method. }\end{array}$ & $\begin{array}{l}\text { Extract fractionation using } \\
\text { alumina or silica. }\end{array}$ & $\begin{array}{l}\text { One of two specified clean up } \\
\text { steps for } C_{10} \text { to } C_{50} \text { range, not } \\
\text { fractionated. }\end{array}$ & $\begin{array}{l}\text { Clean up steps and fractionation } \\
\text { are optional as this may not be } \\
\text { required for each } \\
\text { sample/analytical approach. }\end{array}$ & $\begin{array}{l}\text { Solvent exchange into hexane } \\
\text { followed by K-D evaporation } \\
\text { and treated with silica gel as } \\
\text { described in USEPA method } \\
1664^{64,97} \text {. }\end{array}$ \\
\hline $\begin{array}{l}\text { Analysis } \\
\text { Technique }\end{array}$ & $\begin{array}{l}\text { EPH uses GC/FID*. } \\
\text { VPH may use either GC/FID* or } \\
\text { GC/PID }{ }^{\#} \text {. }\end{array}$ & GC/FID* & GC/FID* & $\begin{array}{l}\text { For the } \mathrm{C}_{10} \text { to } \mathrm{C}_{36} \text { range } \\
\mathrm{GC} / \mathrm{FID}^{*} \text { is used and for the } \mathrm{C}_{6} \\
\text { to } \mathrm{C}_{9} \text { range } \mathrm{GC} / \mathrm{MS}^{\$} \text { is used. }\end{array}$ & $\begin{array}{l}\text { GC/MS } \$ \text {, or GC/FID*, however } \\
\text { the use of GC/MS } \\
\text { to identify unusual mixtures is } \\
\text { noted as being necessary when } \\
\text { analysing by GC/FID*. }\end{array}$ \\
\hline
\end{tabular}


Table 2: Summary of risk assessment used by several different jurisdictions (modified after Environment Agency, $(2003)^{30}$ )

\begin{tabular}{|c|c|c|c|c|c|c|c|c|c|c|}
\hline & $\begin{array}{l}\text { American } \\
\text { Society for } \\
\text { testing and } \\
\text { materials }\end{array}$ & $\begin{array}{l}\text { Massachusetts } \\
\text { Department of } \\
\text { Environmental } \\
\text { Protection }{ }^{53}\end{array}$ & $\begin{array}{l}\text { Total } \\
\text { Petroleum } \\
\text { Hydrocarbon } \\
\text { Criteria } \\
\text { Working } \\
\text { Group }^{84-88}\end{array}$ & $\begin{array}{l}\text { Agency for } \\
\text { Toxic } \\
\text { Substances } \\
\text { and Disease } \\
\text { Registry }^{6}\end{array}$ & $\begin{array}{l}\text { Canadian } \\
\text { Council of } \\
\text { Ministers of } \\
\text { the } \\
\text { Environment }{ }^{18}\end{array}$ & $\begin{array}{l}\text { American } \\
\text { Petroleum } \\
\text { Institute }^{3}\end{array}$ & $\begin{array}{l}\text { Environment } \\
\text { Agency }\end{array}$ & $\begin{array}{l}\text { New } \\
\text { Zealand }^{60}\end{array}$ & $\begin{array}{l}\text { New South } \\
\text { Wales }^{64}\end{array}$ & $\begin{array}{l}\text { National } \\
\text { Institute for } \\
\text { Public Health } \\
\text { and the } \\
\text { Environment }^{10}\end{array}$ \\
\hline $\begin{array}{l}\text { Indicator } \\
\text { Compounds }\end{array}$ & $\begin{array}{l}\text { Uses } \\
\text { 'chemicals of } \\
\text { concern' only. }\end{array}$ & $\begin{array}{l}\text { Use most } \\
\text { toxic and } \\
\text { those most } \\
\text { frequently } \\
\text { tested for. }\end{array}$ & $\begin{array}{l}\text { Uses most } \\
\text { toxic } \\
\text { compounds } \\
\text { only. }\end{array}$ & $\begin{array}{l}\text { Uses most } \\
\text { toxic } \\
\text { compounds } \\
\text { only }\end{array}$ & $\begin{array}{l}\text { Uses most } \\
\text { toxic and } \\
\text { those most } \\
\text { frequently } \\
\text { tested for }\end{array}$ & $\begin{array}{l}\text { Uses most } \\
\text { toxic } \\
\text { compounds } \\
\text { only }\end{array}$ & $\begin{array}{l}\text { Most toxic } \\
\text { and most } \\
\text { prevalent in } \\
\text { petroleum } \\
\text { hydrocarbon- } \\
\text { contaminated } \\
\text { environment }\end{array}$ & $\begin{array}{l}\text { Use of } \\
\text { 'contaminants } \\
\text { of concern' to } \\
\text { address most } \\
\text { toxic } \\
\text { substances } \\
\text { and aromatics }\end{array}$ & $\begin{array}{l}\text { Individual } \\
\text { compounds } \\
\text { identified }\end{array}$ & $\begin{array}{l}\text { Uses most } \\
\text { toxic and } \\
\text { those most } \\
\text { frequently } \\
\text { tested for }\end{array}$ \\
\hline $\begin{array}{l}\text { Fractions } \\
\text { Number }\end{array}$ & None & $\begin{array}{l}6 \text { Analytical } \\
\text { fractions (3 } \\
\text { aromatic, } 3 \\
\text { aliphatic), } \\
\text { using 4 } \\
\text { toxicity } \\
\text { values( } 3 \\
\text { aliphatic, } 1 \\
\text { aromatic. }\end{array}$ & $\begin{array}{l}13 \text { analytical } \\
\text { fractions (6 } \\
\text { aliphatic, } 7 \\
\text { aromatic), } \\
\text { using } 7 \\
\text { toxicity values } \\
\text { ( } 3 \text { aliphatic, } 4 \\
\text { aromatic). }\end{array}$ & $\begin{array}{l}\text { Similar to } \\
\text { TPHCWG. } \\
\text { Minor } \\
\text { modification } \\
\text { to aromatic } \\
\text { groups to } \\
\text { include BTEX } \\
\text { compounds in } \\
\text { same fraction }\end{array}$ & $\begin{array}{l}4 \text { fractions, } \\
\text { based on } \\
\text { TPHCWG, } \\
\text { separate } \\
\text { evaluation of } \\
\text { aliphatic and } \\
\text { aromatic } \\
\text { compounds } \\
\text { not required }\end{array}$ & $\begin{array}{l}14 \text { fractions } \\
\text { based on } \\
\text { TPHCWG ( } 7 \\
\text { aromatic, } 6 \\
\text { Aliphatic and } \\
1 \text { aliphatic and } \\
\text { aromatic } \\
\text { combined) }\end{array}$ & $\begin{array}{l}16 \text { fractions } \\
\text { based on } \\
\text { TPHCWG and } \\
\text { API ( } 7 \\
\text { Aliphatic, } 8 \\
\text { Aromatic and } \\
1 \text { aliphatic and } \\
\text { aromatic } \\
\text { combined ) }\end{array}$ & $\begin{array}{l}3 \text { aliphatic } \\
\text { fractions }\end{array}$ & $\begin{array}{l}2 \text { petroleum } \\
\text { hydrocarbon } \\
\text { fractions }\end{array}$ & $\begin{array}{l}7 \text { fractions } \\
\text { based on } \\
\text { toxicity values } \\
\text { ( } 3 \text { aliphatic } \\
\text { and } 4 \\
\text { aromatic) }\end{array}$ \\
\hline Basis & N/A & $\begin{array}{l}\text { Carbon } \\
\text { number }\end{array}$ & $\begin{array}{l}\text { Equivalent } \\
\text { carbon } \\
\text { number } \\
\end{array}$ & $\begin{array}{l}\text { Equivalent } \\
\text { carbon } \\
\text { number } \\
\end{array}$ & $\begin{array}{l}\text { Equivalent } \\
\text { carbon } \\
\text { number }\end{array}$ & $\begin{array}{l}\text { Equivalent } \\
\text { carbon } \\
\text { number }\end{array}$ & $\begin{array}{l}\text { Equivalent } \\
\text { carbon } \\
\text { number }\end{array}$ & $\begin{array}{l}\text { Equivalent } \\
\text { carbon } \\
\text { number }\end{array}$ & Not defined & $\begin{array}{l}\text { Equivalent } \\
\text { carbon } \\
\text { number }\end{array}$ \\
\hline $\begin{array}{l}\text { Application } \\
\text { of approach }\end{array}$ & $\begin{array}{l}\text { RBCA } 3 \\
\text { tiered look-up } \\
\text { tables for tier } \\
1 \text { and } \\
\text { increasing use } \\
\text { of site-specific } \\
\text { information in } \\
\text { tiers } 2 \& 3 .\end{array}$ & $\begin{array}{l}\text { Not tiered as } \\
\text { appropriate } \\
\text { method is } \\
\text { selected prior } \\
\text { to assessment. } \\
3 \text { methods can } \\
\text { be used - } \\
\text { increasing } \\
\text { specificity } \\
\text { with methods } \\
1 \text { generic } 3 \\
\text { site-specific. }\end{array}$ & $\begin{array}{l}\text { RBCA } 3 \\
\text { tiered look up } \\
\text { tables for tier } \\
1 \text { and } \\
\text { increasing use } \\
\text { of site-specific } \\
\text { into in tiers } \\
2 \& 3 \text {. }\end{array}$ & $\begin{array}{l}\text { RBCA } 3 \\
\text { tiered look up } \\
\text { tables for tier } \\
1 \text { and } \\
\text { increasing use } \\
\text { of site-specific } \\
\text { into in tiers } \\
2 \& 3 \text {. }\end{array}$ & $\begin{array}{l}\text { RBCA } 3 \\
\text { tiered look up } \\
\text { tables for tier } \\
1 \text { and } \\
\text { increasing use } \\
\text { of site specific } \\
\text { information in } \\
\text { tiers } 2 \& 3 \text {. }\end{array}$ & $\begin{array}{l}\text { Modified } \\
\text { TPHCWG } \\
\text { approach. }\end{array}$ & $\begin{array}{l}\text { Modified } \\
\text { TPHCWG } \\
\text { approach } \\
\text { within UK } \\
\text { context. }\end{array}$ & $\begin{array}{l}\text { Use of a 3- } \\
\text { tired } \\
\text { approach, } \\
\text { moving from } \\
\text { generic } \\
\text { guidelines to } \\
\text { less } \\
\text { conservative } \\
\text { values using } \\
\text { site-specific } \\
\text { information. }\end{array}$ & $\begin{array}{l}\text { None } \\
\text { specified }\end{array}$ & $\begin{array}{l}\text { Use of a tiered } \\
\text { approach, } \\
\text { moving from } \\
\text { generic to less } \\
\text { conservative } \\
\text { values using } \\
\text { site-specific } \\
\text { information in } \\
\text { tiers } 2 \text { and } 3 \text {. }\end{array}$ \\
\hline
\end{tabular}




\begin{tabular}{|c|c|c|c|c|c|c|c|c|c|c|}
\hline & $\begin{array}{l}\text { American } \\
\text { Society for } \\
\text { testing and } \\
\text { materials }\end{array}$ & $\begin{array}{l}\text { Massachusetts } \\
\text { Department of } \\
\text { Environmental } \\
\text { Protection }\end{array}$ & \begin{tabular}{|l} 
Total \\
Petroleum \\
Hydrocarbon \\
Criteria \\
Working \\
Group \\
\end{tabular} & $\begin{array}{l}\text { Agency for } \\
\text { Toxic } \\
\text { Substances } \\
\text { and Disease } \\
\text { Registry }\end{array}$ & $\begin{array}{l}\text { Canadian } \\
\text { Council of } \\
\text { Ministers of } \\
\text { the } \\
\text { Environment }\end{array}$ & $\begin{array}{l}\text { American } \\
\text { Petroleum } \\
\text { Institute }\end{array}$ & $\begin{array}{l}\text { Environment } \\
\text { Agency }\end{array}$ & New Zealand & $\begin{array}{l}\text { New South } \\
\text { Wales }\end{array}$ & $\begin{array}{l}\text { National } \\
\text { Institute for } \\
\text { Public Health } \\
\text { and the } \\
\text { Environment }\end{array}$ \\
\hline Analysis & $\begin{array}{l}\text { No } \\
\text { recommended } \\
\text { method of } \\
\text { analysis }\end{array}$ & $\begin{array}{l}\text { Use of two } \\
\text { methods } \\
\text { developed by } \\
\text { MaDEP for } \\
\text { volatile } \\
\text { petroleum } \\
\text { hydrocarbons } \\
\text { (VPH) }{ }^{57} \text { and } \\
\text { Extractable } \\
\text { petroleum } \\
\text { hydrocarbons } \\
(\mathrm{EPH})^{56} \\
\end{array}$ & $\begin{array}{l}\text { The 'Direct } \\
\text { Method', } \\
\text { developed by } \\
\text { AEHS. }\end{array}$ & $\begin{array}{l}\text { The 'Direct } \\
\text { Method'1 }\end{array}$ & $\begin{array}{l}\text { Benchmarked } \\
\text { methods for } \\
\text { the } C_{6} \text { to } C_{10} \\
\text { and } C_{10} \text { to } C_{50} \\
\text { ranges }{ }^{19} .\end{array}$ & $\begin{array}{l}\text { Modified } \\
\text { 'Direct } \\
\text { Method' for } \\
\mathrm{C}_{44}+\text { range. }\end{array}$ & $\begin{array}{l}\text { No specified } \\
\text { methods, } \\
\text { however are to } \\
\text { adopt } \\
\text { performance } \\
\text { criteria - } \\
\text { MCERTS }^{32}\end{array}$ & $\begin{array}{l}\text { Use of } \\
\text { method } \\
\text { prepared by } \\
\text { the Oil } \\
\text { Industry } \\
\text { Environment } \\
\text { Working } \\
\text { Group }^{6} \text {. }\end{array}$ & $\begin{array}{l}\text { Dependent on } \\
\text { source of } \\
\text { threshold } \\
\text { concentration. } \\
\text { Using NEPC } \\
\text { methods }^{63} \text {. }\end{array}$ & $\begin{array}{l}\text { Single } \\
\text { analytical } \\
\text { method (NEN } \\
5733 \text { ) } \\
\text { recommended }\end{array}$ \\
\hline $\begin{array}{l}\text { Additivity } \\
\text { effects }\end{array}$ & $\begin{array}{l}\text { Not } \\
\text { recommended }\end{array}$ & $\begin{array}{l}\text { Precautionary } \\
\text { based on } \\
\text { addition of } \\
\text { hazard } \\
\text { quotients } \\
\text { across } \\
\text { fractions }\end{array}$ & $\begin{array}{l}\text { Precautionary } \\
\text { based on } \\
\text { addition of } \\
\text { hazard } \\
\text { quotients } \\
\text { across } \\
\text { fractions }\end{array}$ & $\begin{array}{l}\text { Precautionary. } \\
\text { Developing } \\
\text { index of } \\
\text { concern based } \\
\text { on addition of } \\
\text { hazard } \\
\text { quotients } \\
\text { across } \\
\text { fractions for } \\
\text { compounds } \\
\text { affecting same } \\
\text { target organs } \\
\text { of systems } \\
\end{array}$ & $\begin{array}{l}\text { Not advised } \\
\text { due to } \\
\text { different } \\
\text { toxicological } \\
\text { end points and } \\
\text { exposure } \\
\text { pathways of } \\
\text { different } \\
\text { fractions }\end{array}$ & $\begin{array}{l}\text { Precautionary } \\
\text { based on } \\
\text { addition of } \\
\text { hazard } \\
\text { quotients } \\
\text { across } \\
\text { fractions }\end{array}$ & $\begin{array}{l}\text { Assumes } \\
\text { additivity of } \\
\text { toxicological } \\
\text { effects across } \\
\text { all fractions, } \\
\text { unless there } \\
\text { are scientific } \\
\text { data to the } \\
\text { contrary. }\end{array}$ & $\begin{array}{l}\text { Additivity of } \\
\text { excess lifetime } \\
\text { cancer risk for } \\
\text { non- threshold } \\
\text { substances. } \\
\text { Precautionary } \\
\text { approach, as } \\
\text { for ATSDR }\end{array}$ & $\begin{array}{l}\text { Not discussed } \\
\text { in guidance } \\
\text { document }\end{array}$ & $\begin{array}{l}\text { Precautionary } \\
\text { approach, } \\
\text { based on } \\
\text { addition of } \\
\text { hazard } \\
\text { quotients } \\
\text { across } \\
\text { fractions }\end{array}$ \\
\hline Range & & $\begin{array}{l}n \mathrm{C}_{5}-n \mathrm{C}_{36} \\
\text { Aliphatics, } \\
n \mathrm{C}_{9}-n \mathrm{C}_{22} \\
\text { Aromatics }\end{array}$ & $\begin{array}{l}\mathrm{EC}_{5}-\mathrm{EC}_{21} \\
\text { Aliphatics, } \\
\mathrm{EC}_{5}-\mathrm{EC}_{35} \\
\text { Aromatics } \\
\end{array}$ & $\begin{array}{l}\mathrm{EC}_{5}-\mathrm{EC}_{21} \\
\text { Aliphatics, } \\
\mathrm{EC}_{5}-\mathrm{EC}_{35} \\
\text { Aromatics } \\
\end{array}$ & $\mathrm{EC}_{6}-\mathrm{EC}_{50}$ & $\mathrm{EC}_{6}$ to $\mathrm{EC}_{44+}$ & $\mathrm{EC}_{5}$ to $\mathrm{EC}_{70}$ & $\mathrm{EC}_{7}$ to $\mathrm{EC}_{36}$ & $\mathrm{EC}_{6}$ to $\mathrm{EC}_{40}$ & $\mathrm{EC}_{5}$ to $\mathrm{EC}_{35}$ \\
\hline
\end{tabular}


1152

1153

1154

1155

1156

1157

1158

1159

1160

1161

1162

1163

1164

1165

1166

1167

1168

1169

1170

1171

1172

\section{List of main acronyms and definitions}

API American Petroleum Institute

ASTM American Society for testing and materials

ATSDR Agency for Toxic Substances and Disease Registry

BTEX Benzene, toluene, ethylbenzene and xylene

CCME Canadian Council of Ministers of the Environment

EA Environment Agency (UK)

EPH Extractable petroleum hydrocarbon

GC

Gas Chromatography

GC-MS Gas Chromatography mass spectroscopy

GC-FID Gas Chromatography with flame ionisation detection

MaDEP Massachusetts Department of Environmental Protection

PAH Polynuclear aromatic hydrocarbons

RIVM National Institute for Public Health and the Environment

TNRCC Texas Natural Resource Conservation Commission

TPH Total petroleum hydrocarbon

TPHCWG Total Petroleum Criteria Working Group

UCM Unresolved complex mixture

USEPA United States Environmental Protection Agency

VPH Volatile petroleum hydrocarbon 